\title{
An Ecological Journey to Pandam through Mulgaon Areas of Darjeeling Himalaya with Special Reference to Monitoring Of Vegetation in West Bengal, India
}

\author{
Debabrata Das \\ Angiospermic Taxonomy and Ecology Laboratory, Post Graduate Department of Botany \\ Darjeeling Govt. College, Darjeeling, West Bengal, India \\ Ex-JRF, CNH, ICFRE Project, Ex-JRF, SRF, CNH, BSI, Howrah-1, West Bengal, India
}

\begin{abstract}
The paper reflects the ecological dynamics of vegetation with special reference to burning problems that are increasing day by day in villages of Darjeeling Himalaya of West Bengal, India. It includes floras (Roadside, shrubberies, jungles, forests, agricultural land, ridges and furrows of barren hill slopes, near waste water falls, near fresh water falls, grass lands, gardens of private kind, pasture land, vest land etc.), some faunas, agriculture, forestry etc. of the villages. The article also reflects some ecological problems of Eastern Himalaya particularly in Darjeeling area where water problem is severe one including different occupational problems. Sexual problem is also another problem in hills which is related with sexually transmitted diseases (STDs). The drinking water of the hill is not good, because they use locally available water coming from source of top hills by normal leaching process. Therefore, in ecological journey author broadcasts transportation problems of water as well as for life-style of people have been discussed thoroughly. Education and research problems is also highlighted in this article, so as a whole the paper is a nominal one facing scenario of Ecological Problems and prospects of the same. Here, author highlights dynamics of vegetation through which people can mitigate the ecological problems and easily can restore ecosystem pristine in hill villages of Darjeeling Himalaya. This would be helpful for different researchers and students of PG and UG courses to take research problems during project dissertation and post $P G$ students for research and extension programme in the said area. Not only that, I think in near future NGOs and Government should take care to develop different projects at the premises of the Hill villages so that they would take the opportunity for all round development of the society. As a whole, the eco-restoration of the habitat would be better through the research and extension programme in such areas via a model example in all rural areas of hills. Institutions and departments will generate opportunity to work there if become interested through this article with some examples thereby.
\end{abstract}

KEYWORDS: Mulgaon vegetation dynamics and trends of Succession, Agriculture-Water related problems, Food-Fodder, Economy to Ecology, Eco-restoration.

\section{INTRODUCTION}

Darjeeling Himalaya fall under Eastern Himalayan region in India which is situated between $87^{\circ} 59^{\prime}$ $88^{\circ} 53^{\prime} \mathrm{E}$ and $28^{\circ} 31^{\prime}-27^{\circ} 13^{\prime} \mathrm{N}$ in the northern part of West Bengal State of India. It has an area of 3,149 sq km. The annual mean maximum temperature is $14.9^{\circ} \mathrm{C}$ and annual mean minimum temperature is $8.9^{\circ} \mathrm{C}$ and average annual rainfall is $3092 \mathrm{~mm}$. (Sharma, 2013). The altitudinal range of this hilly region varies from 150 to 3636 meter resulting in a huge contrast and diversity in climate and vegetation (Saha et al, 2011). The district is surrounded by Bhutan in the east, Nepal in the west and Sikkim of India in the north. Due to similar environmental and cultural conditions, the major inhabitants of Darjeeling hills and its surrounding areas are bonded together by Nepali language, the medium of communication among the different ethnic groups, viz. Lepchas, Bhutias, Rai, Sherpa, Tamang, Mangar, Gurung and Kagatay of the Nepali communities (Rai and Bhujel, 1999). Traditionally, chief occupation of the people of Darjeeling had been agriculture, agro forestry, horticulture and animal husbandry. A wide range of microclimatic sites under a wide array of climatic zones are available here, that allow growing more luxuriant biota in a proper naturally managed environment. The climates favour the luxuriant growth of diversified floral and faunal elements and make the vegetation as a climatic climax. Therefore, the gradient of this region is also diverse with gentle range of natural flora. So, the area boosts luxuriant growth of ground vegetation of angiosperms along with different mosses, liverworts, lichens, fungi, algae and cyano-bacteria. The shrubby vegetation of different members aggregate the small patches along the dominant tree species there in a two or three layered canopy system, which have high coverage of litter fall. 
Not only the coverage of floral elements, there present many endemic, rare, threatened and endangered category. A good number of populates are present there in a remote village nearby and collecting plant material for their home garden. These also found in their homesteads, in crop fields and in communal lands. The exact situation about the position of plant and their uses are still not cleared due to landing a less number of biosocial research projects. So, practice and enumeration regarding the fate of plants of important groups are necessary to clarify the ecological problems in the said area and to draw a managerial line between the source and sink of the plants or the plant products in near future. Therefore, in this communication, an attempt has been made to document the vegetation first time as preliminary study for the floral elements present in the remote areas of hilly Darjeeling along with the fate of them. Ethnic knowledge as well as scientific knowledge of the people and the environmentalists of rural Darjeeling Himalaya has been raised to enforce the ecosystem sound and healthy in near future. So, as a whole this is a study of vegetation dynamics and monitoring of ecosystem through different ways to clarify the situation which is formally unknown to all. It includes the data base of the eco-research of some patches with the help of local resource persons to measure the ecosystem sound and eco-friendly. Vegetation is always playing a key role to sustain the environment normal even take part as a relation (kith and kin) to the biota of other kind virtually as god. Darjeeling Himalaya is a similar kind of nature friendly ecosystem which boosts so many types of floral elements in varied ecosystems. A large number of plant species found here which have significant role to sustain the life-style of Darjeeling peoples in a need based way by different mode.

The forests are dominated mostly by local tree species and other common plants viz. Alnus nepalensis (Utis), Schima waliichii (Chilauney), Mallotus alba (Jogi Malata), M. roxburghianus (Fushrey Malata), Bischofia javanica (Kaijal), Bassia butyraceae (Chewri), Betula alnoides (Saur), Firmiana colorata (Firfiray), Ficus cunia (Khanew), Styrax serrulatum (Khanew), Sterculea villosa (Odal), Cephalostachyum capitatum (Payong), Brassiopsis mitis (Chulatro), Duabanga sonneratioides (Lampatey), Viburnum colebrookianum (Asaray), Cinelina arborea (Khamari), Ficus nemoralis (Dudalo), F. benjamina (Ber), Ficus religiosa (Pipal), Quercus lanceafolia (Katus), Morus indica (Kimbu), Fraxinus paxiana var. sikkimensis (Lakuri), Andromeda villosa (Angeri), Shorea robusta (Sal), Eupatorium cannabinum (Kalo banmara), Costus speciosus (Betlauri), Artemisia vulgaris (Titaypati), Laportea terminalis (Sisno), Heracleum walichii (Chimphing) etc. (Bhujel, 1996).

All the people of the remote area are very poor as they collect food, fodder, wood, medicine, sticks of bamboos and bet (Calamus sp.) from local environment for different purposes. All the villagers have terrace crop cultivation. The principal crops cultivated are maize, rice, pulses, millets, etc. but most of the villagers earn their living by cultivating cash crops like Darjeeling Mandarin orange, ginger, and large cardamom (Rai, 2001). Medicinal Plants of the village as well as in town plays a significant role to health care system of the people. In, Darjeeling it is not yet been bad as habitat, because people of Darjeeling use these plants for healing purpose as well for research and extension through different departments, to popularize the plants as well as for the sake of extension activities and ornamental purpose. Herbaceous medicinal plants are common one that has the potential for use value round the year in every part of the area. In a study Rai et al. (2013) studied 57 plat species belonging to 55 genera with their therapeutic values against different diseases occurring in Darjeeling Hills. They showed that, out of these plants studied, 38 species they used as herbs, 9 shrubs and 10 are trees. They also showed that, herbs are more useful than the shrubs and trees and most of the plant species they used for more than one purpose.

The Himalayan Jungles have been home to the most exotic species of flora and fauna. The short spring season sees the mountain bathed in all conceivable hues. The fiery Rhododendrons splash the mountainside in the most beautiful reds, whites and the pale magnolia forests providing a striking contrast. The valley too comes alive with a profusion of daises, daffodils, Chrysanthemum and tuberous Begonia. Orchids even the rarest grow in abundance in the wild. Amidst this dazzling flora is a fauna equally exotic. The Red Panda is found in the dense jungles between Gairibas and Molley on the way to Sandakpu. The Barking deer, wild boar and Himalayan beer are the other animals that are found here. The Padmaja Naidu Zoological Park is also a special attraction being the highest Zoo in the world. Darjeeling is also the abode of a variety of birds and butterflies (Anonymous, 2012).The present study area comprises vast tea gardens with some planted sites, under which people make their own arrangement to earn money and trying to develop economy for betterment of the society. As the tract is very stiff, so they use feet to come in to the town Darjeeling or nearby Lebong market or Threemile (Tin mile) market with the help of motor cycle or by 4 wheelers. The distance from Darjeeling Chowrasta to Pandam is near about $3.5 \mathrm{~km}$ along the partially metallic road so called Lower Toong Soong. Lebong market is near about $3 \mathrm{~km}$ from Pandam Tea Estate, where as Tin-mile is nearly about 12-13 kms by newly constructed road made by stone. The road is sanctioned during the present Trinamool Government (West Bengal), and will be made as metallic one from Lebong to tin-mile through Pandam by the active participation of the local administration popularly called GTA. The site is very beautiful and naturally designed by trees of varied types, shrubs and gregariously grown a huge number of Himalayan grasses along with sedges. A beautiful temple and tea garden is there beside the left hand side of the road. Some sites having species of plantation type, namely 
Rhododendrons along with the Euphorbia's and Ficus spp. The magnificent exotic species like Prunus sylvestris, Michelia sp. etc. are found here and there near the tea garden. A stable is there which hosts 4-5 horses used to collect plucked tea leaves from lower part of stiff garden and brought it to the factory. So, use of animal for present day activity in the said area is meaningful and using the majestic culture till date though technology based recent techniques have been evolved in other part of the state tea gardens. In hill areas, particularly at villages of Sub-Himalaya, the adolescent girls face health related problems which are Night blindness, Angular stomatitis, Dental caries, Hemoglobin deficiency, Iodine deficiency goiter (Saha et al., 2006). In the same areas they face Sexually Transmitted Diseases (STDs) which are very much problematic. The same authors showed in a paper that, sexual awareness and contraceptive knowledge in tea garden areas are poor in comparison to the adolescent girls of urban areas. Here, result of the same showed that $7.85 \%$ girls of the tea garden area are sexually active, $4.2 \%$ has history of sexual abuse, $6.4 \%$ has suffered from STDs, $4 \%$ had abortions, and $63.5 \%$ has contraceptive knowledge, which they obtained from older peers. $95 \%$ of School Girls were sexually aware. $62.3 \%$ of them knew about contraceptive from peers and other public media. Five percent of tea garden girls were married and $20 \%$ of them had experienced pregnancy. So, problems including STDs of the said area are varied which need detailed survey and need elaborate discussion to prevent the same in an urgent basis. So, as a whole they face a large number of occupational diseases in the area of Eastern Himalaya. The present site needs survey and identity of such special problems as ecological one to signify the people and the culture in a tourist rich eco degradation area. The real story of such full path establishment of social degradation may help the study of eco-restoration in near future with the help of different workers in the same field. Such kind of eco-restoration, perhaps need significant role to the community in the specific kind of restoration in near future. Psychologists and doctors should take part of this study to fulfill the study a real one and culminate the goal in to a platform to study the whole along the eco-restoration of land and vegetation as a whole with the study of people and diseases.

\section{AREA UNDER STUDY}

The study area includes the area of lower hills of Darjeeling facing eastern part of Mall of Darjeeling which comprises mostly the 16 square kilometer area in hill slopes. Journey started from Chowrasta (4 angular ways) i.e. from Mall to Udaygram, to Mulgaon, to Pandam to Golaigaon to Limu Basty to Jowary Basty to Chorasta. Areas covering for the study were local markets nearby and the villages including the shrubberies and gardens of public kind along with forests of natural types for vegetation and their similar products via market study. Truly the areas covering for monitoring of vegetation are villages like Basbote, Sourini, Kulungdara, Ardhure, Mulgaon, Cohukidar dara, Jowary basty, Limbu Basty, Mulgaon, Golaigaon etc. Some natural falls of sewage water including fresh water falls have been taken to study. To discuss with ecological problems personnel garden and Company gardens (Tea Garden of Pandam) have also been incorporated for this study. Plantation stand of agricultural type like Ginger and Cardamom, gardens have also been studied with the shade trees of the same area. Tea Garden and similar gardens were studied to discuss the eco-restoration activities of the said area. Herbaceous vegetation along with sedges and hedges were critically examined regarding their phenology and variations with the variations of seasons. For the study, introduced plants of roadside kind and in the vested land of both the sites were taken for study.

\section{OBJECTIVES OF THE STUDY}

The Present study includes some ecological problems of Darjeeling Himalaya, West Bengal, India. For the eco-sustenance of vegetation and people; study, research and extension is necessary for each village everywhere. Therefore, this study is a preliminary study to highlights the problems and prospects of research including extension of the same for those villages which need immediate evaluation after monitoring. Because, environmental degradation is going on, so as a whole, ecosystem going to be vulnerable day by day and no one is involved to highlight the same before mitigate the problem through different models. So, it needs immediate work there on the environment as a urgent basis and in the same field even need monitoring of different parameters to save the ecosystem good and healthy which can change the scenario of the land and people of the Darjeeling Himalaya in a sustainable basis. To highlight the burning problems, and to start the work there, the author represents the points that are required to clarify after working there with viable projects. To monitor the projects in different fields and to save the ecosystem and eco-resource as a whole involvement of local people and Govt. including Institutes and NGOs are to be required. Following are the points that are required to become the environment eco-sustainable state via common monitoring at least $1 / 2$ a year interval basis. This includes no remote sensing like sophisticated techniques, but need physical monitoring by students and teachers of nearby institutes along the local people to start intervention by locale people on the basis of low level application which 
can mitigate the problem and can tolerate the eco-problem developed day by day in the said unhealthy ecosystem. So, always remember the points before going to physical monitoring:

(1) Study of Vegetation which includes the study of flora of Roadside, Shrubberies, Jungles, Forests, Agricultural land, Ridges and Furrows of barren hill slopes, Near waste water falls, Near fresh water falls, Grass lands, Gardens of private kind, Pastureland, Vest land etc.

(2) Study of some faunas, by indirect way along the help of local resource persons of the jungle. The study of fauna on secondary data is also predicted if primary data is not available.

(3) Study of problems in Agriculture, Forestry, Farm forestry, etc. of the villages.

(4) To study the severe water problem and fate of the water related problems.

(5) To study of Health and occupational diseases including Sexually Transmitted Diseases (STDs).

(6) To broadcast transportation problems of water as well as for life-style of people.

(7) Education and research problems in the area and area based extension on peoples' thought.

(8) Role of Institutions, Non Government Organization (NGO) and Government.

(9) Guideline for preparation of Healthy atmosphere through eco-monitoring, and to become the environment pristine as a whole the ecosystem under good health status.

(10) Modeling the area to solve problems after implementation of good projects to mitigate the situation in a global way but sustainable basis (Phase-II).

It includes different sections:

\section{MATERIALS AND METHODS}

Study of vegetation and monitoring of succession:

Varieties of methods are available for monitoring the succession. Selection of monitoring methods depends mainly on the timeframe and budget of the restoration project. Monitoring succession requires initiating long-term ecological evaluation on restoration sites. For this purpose permanent plots are often used where measurements on vegetation dynamics can be repeated over several years. Data obtained from permanent plots include taxonomical survey of plants and measurements on vegetation cover. Permanent plots provide data for the interpretation of succession and also allows for testing of various management practices in restoration (Greipsson, 2011; Groom et al., 2006). For preliminary study, 2 years project have been taken for consideration in Mulgaon forest area near Pandam and Golaigaon area and is also taken for the study which have no critical barrier to work there from Chowrasta area of Town Darjeeling, West Bengal, India. Three types of vegetation have been taken for study. These are Village vegetation including agricultural plants, shrubberies near village and forest vegetation. For the study of vegetation cover, only forest area has been taken for study since 20012 to 2013 and from 2013 to till date. Only $5 \mathrm{~m}^{2}$ Plots were taken to study grasses, herbs and low shrubs. Permanent plots in tall shrubs communities and for trees have been taken $100 \mathrm{~m}^{2}$ area.

\section{Study of Vegetation Cover and study of restoration action:}

Vegetation cover can be measured by a variety of methods, such as the "Point intercept" method that is practical for small plots, the "line intercept" method, or by using aerial photos for large plots. Canopy cover of trees can also be estimated by using aerial photos. Methods to estimate diversity of tree species involve plot and plot-less sampling methods. In the plots, species composition, litter, and soil cover should be recorded over time. This requires taxonomical knowledge on the local flora. Photos on permanent plots taken repeatedly through time can provide valuable information on succession. Such images provide rapid estimation on the cover of each species. The use of digital images of permanent plots is a new technique that allows rapid documentation of vegetation dynamics. Such images can be calibrated in the field before being analyzed. It is then to estimate rapidly the total cover of each species using computers (Greipsson, 2011). In the present study line intercept method was taken to study the vegetation in forest. For small shrubs and herbs graph paper method was taken for consideration, though there are several methods for this study. Abeny's level was taken for the study of measuring height of trees and altimeter was taken to record the height. As the study is $1^{\text {st }}$ phase and as preliminary one, so the author used Canon camera 12.1 megapixels (4 x Optical zoom) for vegetation photography during field visit. Another camera used was Nikon (Model-16.0 megapixels CMOS Glamour Retouch (Wi-Fi) with wide 6x zoom-coolpix. Taxonomic identity of species, authors consulted with local resource persons (See Table 1) from which local names of plants and some nonliving items were recorded. Authors also collected sample specimens for taxonomic identity, from the field using voucher number and date including habitat of microclimatic type. To match the local names with the actual scientific names of the species, dictionary of flowering plants of Darjeeling-Sikkim Himalaya, was consulted (Tamang and Yonzone, 2012). Other books consulted were Flowers of the Himalaya-A supplement (Adam Stainton, 2011) and Flowers of the Himalaya (Polunin and Stainton, 2012). Identification was done with the help of standard literature (Hooker 1892-1897; Prain, 1963; Anonymous, 1997; O’Malley, 1907; Das, 2007). The names of the plants were cross checked and finally incorporated following Bennet (1987). Herbarium specimens and museum specimens 
were prepared as per the methodology of Jain and Rao (1997). For medicinal uses of plants, different books and related publications have been consulted but for general use the common book used was Kirtikar and Basu (1918). Some scattered literatures were used for different purposes to study the social aspects (Malhotra et al., 1991; Roy et al., 2000). Specimens of collected one temporarily pressed and preserved under personal custody and compared with some of the housed specimens of Lloyd Botanic Garden Herbarium, Darjeeling. As the author studied some revisionary works on Betulace and Juglandaceae from Central National Herbarium, Botanical Survey of India, and so conformity already have done due to critical analyses specimens and literature as a whole.

\section{Analysis of Data for the study of Vegetation Dynamics:}

To study and analyses the phytosociological characters, over all study of floristic composition, characteristics of vegetation, size, shape, fluctuation and dynamics have been studied critically round the last two years. The overall parameter signifies the sociability indices in the community of plants, in the forests of the study sites. Within the site Moua tree (Engelhardia sp.) and Laliguras tree (Rhododendron sp.) are the dominated members of the community in forests. Other species found there are Erythrena sp. and Mallotus sp. including some members of Meliacaea and Juglandaceae. All the species cover the area with more than $75 \%$ canopy cover in terrain of highly stiff hill face. By and large, index of Dombois and Ellenberg (1974) have been adopted to analyze the density, frequency and abundance of the tree species. For the study of frequency, density and abundance of the species, following formulae were used. So, the-Density=Total number of individuals in all sampling units/total number of sampling units studied. Frequency $=$ Number of sampling units in which species occur x 100/Total number of sampling units used. Basal Area is the area occupied by the base of a tree, is considered as a good indicator of the size, volume or weight of a tree. It provides information on the proportion or dominance of the larger and smaller trees in an ecosystem and is one of the most important parameters in estimating the standing biomass in an area. The DBH have been taken for study was 1.37 meter. Following the DBH, basal area and cover of each individual have been made. So, Basal area $=\mathrm{GBH} 2 / 4 \pi$ Where GBH $=$ Girth of the tree at breast height. Usually after the quantitative estimation of relative values of density, frequency and dominance, the species are listed in order of decreasing importance so, as to present the criticalness in the stranded vegetation community for future study.

\section{Study of Cumulative Phytosociological Characters}

Importance Value Index (IVI) is the cumulative phytosociological characters. The total picture of the relative ecological important and the phytosociological structure of a given plant species in any community can't be obtained by relative parameters (Relative Frequency, Relative Density, Relative Dominance, etc.,) singly, which give individual clues, although the quantitative value of each such parameter has its own importance. Therefore, Frequency gives an idea as to how a species is dispersed in the area but we will not get an idea about its actual number or pattern in the said area covered. Density on the other hand gives rise to the numerical strength of the vegetation and signifies nothing about the spread or cover. Dominance gives the basal cover of the vegetation elements so is the only sole number to access the parameter by using only one value. In order to express the dominance and ecological success of any species with a single value, the concept of important value index have been developed. This index utilizes three characteristics, viz., Relative Frequency, Relative Density and Relative Dominance of the composition in a given community. On the basis of these analytical quantitative character values, the idea of obtaining a statistical quantity was proposed. This is replaced by a value of other kind in order to have a really overall picture of the ecological importance of the species in a selected community to express them with respect to the community structure, and composition, for which the percentage value of Relative Frequency, Relative Density and Relative Dominance are added together. This value out of 300 is called Important Value Index (IVI). It thus incorporate three important parameters that measures of productivity and diversity of every species therefore. So, IVI= Relative Density + Relative Frequency+ Relative Dominance. To access the structure and composition any two parameters except frequency or as a whole the IVI may be consider studying the vegetation. The present study is based on the IVI of tree species only except, herbs, shrubs in the said community. So, Relative density = Density value of species x 100/ Sum of density value of all species. Similarly, Relative frequency $=$ Frequency value of species x 100/ Sum of frequency value of all species, and Relative dominance $=$ Total basal area of the species x 100/ Total basal area of all species.

\section{Other indices for the study of Phyto-diversity:}

Ecologist always tries to formulate and develop a special index to calculate the index to quantify the vegetation. So, all field ecologists have developed and proposed a number of indices of species diversity from time to time. So, by them the values of the vegetation which depend upon mathematically combined effects of species richness (d) and evenness (e). The numerical strength and biomass has a direct affect on the functioning 
of ecosystem in the course of millions of years, numerous biotic communities have evolved and established themselves. It is therefore, important to know the diversity of these communities in space and time so as to understand their role in the development of the ecosystem, healthy and sound. To evaluate these healthy ecosystem, structure study along the study of function and in the maintenance of stability as a whole for the quantification of diversity. Not only that, it needs to clarify the composite structure along with the comparison of species diversities between nearby two different ecosystems under varied eco-climatic conditions. Therefore, the index formulated and applied for the same is called index of diversity and dominance.

\section{Study of Species Richness (Species Diversity)}

Species diversity or richness diversity is an expression of community structure. It is described as the number of species present in a sample or habitat per unit area basis. These are certain indices that can bring them to a similar scale for a specified field and for specific group of plants, say for example herbs, shrubs and trees. The simplest species richness index is based on the total number of species and the total number of individuals in a given sample or habitat, higher the value greater the species richness (Rao et al., 2013; Dey, 2013). The more different species present the more diverse the community and is generally considered healthier. Richness tends to increase over area larger areas will harbors more different species probably because of larger variety of micro habitats and resources. Additionally, sampling over a large area increases the chance of find in rare species. On the other hand, evenness is a measure of how similar the abundances of different species are categories are in a community. Evenness is ranged from zero. When the evenness is close to one, it indicates that each species categories consist of almost same number of individuals. However, when the abundances of species are very dissimilar (Some rare and some common) then the value increases. The commonly used biodiversity index is Shannon-Wiener index and that of dominance index is Simpson's index. Simpson's Index (1949): Species dominance is measured by using this index $\mathrm{Cd}=\Sigma(\mathrm{ni} / \mathrm{N})^{2}, \mathrm{ni}=$ Total number of individuals of each species , N = Total number of individuals of all species. Shannon - wiener Index (1963): It is also called species diversity index. This index is based on information theory and improves upon the Simpson's by giving more importance to the rare species. $\mathrm{H}=\Sigma(\mathrm{ni} / \mathrm{N}) \log (\mathrm{ni} / \mathrm{N})$. where, $\mathrm{ni}=$ Total number of individuals belonging to $\mathrm{i}^{\text {th }}$ species and $\mathrm{N}=$ Total number of individuals in the sample (Das, 2007).

\section{RESULTS AND DISCUSSION}

The Present paper revealed 103 phyto-elemnts in and around Pandam areas and Mulgaon forests of Darjeeling Himalaya which have potential economic as well as ecological value. These are used broadly as medicinal one, used for food and fodder, for vegetables, for fibres, flosses, economically important fruits as well as for tubers of varied kinds during drought and heavy monsoon (Table 2). Some species are used as ornamentals in the premises of villagers with varied economic values. As for example, sunakhari and sunakhar in the rocky walls near the buildings and village huts. They make the environment very pleasant and charming type. Not, only the said purposes, they used the underground part of some plants, and above ground biomass also they used for medicinal purpose. Good example is Bargenia ciliata (Pakhan bet). Other elements used for the purpose like fuel wood, wood, implements, house fence, sticks in their own kitchen gardens. Near the hilly slopes, they used tuber crops of various kinds like Sechium sp., Yams and Tarul (Photo plate 7). To develop market economy they used a large number of bamboos and bet from the forest and village shrubberies. Green leaves are also used to different purposes.

Table 1 Resource Persons based field Study at Golaigaon, Mulgaon, Pandam at Darjeeling Himalaya, W.B., India.

\begin{tabular}{|l|l|l|l|}
\hline \multicolumn{1}{|c|}{ Sl. No. } & \multicolumn{1}{|c|}{ Name } & \multicolumn{1}{|c|}{ Address } & \multicolumn{1}{|c|}{ Phone No. } \\
\hline 1 & Bishnu Prasad Sharma & Mulgaon, Udaygram, Darjeeling, 734101 & $\begin{array}{l}\text { Ph-07872941985/09609931334 } \\
\text { Resource person) }\end{array}$ \\
\hline 2. & Chandan Sharma & Mulgaon, Udaygram, Darjeeling, 734101 & Ph-09733022281 (Service) \\
\hline 3. & Sovit Chhetri & Mulgaon, Udaygram, Darjeeling, 734101 & Ph-09800003386 (Carpenter/Electrician) \\
\hline 4. & Dhirendra Pradhan & Pandam Tea Estate, Darjeeling, 734101 & Ph-09635292576 (Small Canteen) \\
\hline 5. & Kamal Kumar Roy & $\begin{array}{l}\text { Non-Teaching Staff, Darjeeling Govt. } \\
\text { College, Darjeeling, 734101 }\end{array}$ & Ph-9775946360 (Knowledge on Nepali) \\
\hline 6. & I.K.Gurung & Pandam, Darjeeling, 734101 & $\begin{array}{l}\text { Ph-09434151123, (Retd. Staff of PNZP), } \\
\text { Ex-Student, DGC, Zoology. }\end{array}$ \\
\hline 7. & Lakshmi Chhetri & Mulgaon, Udaygram, Darjeeling, 734101 & Ph-Nil, House wife (Class XII -Sc.) \\
\hline Total-7 & Persons involed in field. & & \\
\hline
\end{tabular}

A good example is vegetables and sacred plant like bar producing leaves, including totala (Oroxylum indicum Vent.). Winged Seeds are also important because, they used seeds in front of the door for sacred 
purpose. Some house premises used leaves of Bar and similar type as religious plants. So, nearly $55 \%$ of the plants, they used are the plants of wild origin. In the garden they planted Farshi (Cucurbita pepo), Es-kush, sweet pea, bean, broad bean etc. Cattle and domestic bees are the resource of another kind they used for meat, milk, honey producing purposes respectively. Katus (Castanopsis sp.), Chanp (Michelia sp.), Moua (Engelhardia sp.) and Gogun (Saurauia sp.) are the important wood used for fuel wood purpose.

Table 2

List of Plants arranged as per local/common names including scientific names available in rural villages of Darjeeling Himalaya, West Bengal with proper usage.

\begin{tabular}{|c|c|c|c|}
\hline Local Name & $\begin{array}{c}\text { Scientific Name } \\
\end{array}$ & Short Note & Uses \\
\hline Ailo & $\begin{array}{l}\text { Didymocarpus aromaticus Wall. Ex D. } \\
\text { Don. }\end{array}$ & Herb of Gesneriaceae & $\begin{array}{l}\text { On shady wet rocks near jhora } \\
\text { (falls). }\end{array}$ \\
\hline Amliso /Kucho & $\begin{array}{llll}\text { Thysanolaena } & \text { maxima } & \text { (Roxb.) } & \mathrm{O} \\
\text { Kuntze. } & & & \end{array}$ & Shrub of Poaceae & $\begin{array}{l}\text { Used as broom called } \\
\text { Phuljharu (Beng.), in Nepali } \\
\text { called "kucho", also used as } \\
\text { fodder for cattle in villages. }\end{array}$ \\
\hline Angairi & Lyonia ovalifolia (Wall.) Drude & Small tree of Ericaceae & $\begin{array}{l}\text { Fodder plant, wood used as } \\
\text { fuel wood. }\end{array}$ \\
\hline Angare/Aule & Phoebe attenuate Nees. & Lauraceae & Medicinal Plant. \\
\hline Angeri & Osbeckia stellata Wall. & Shrub of Melastomaceae & $\begin{array}{l}\text { Indicator sp. Indicates village } \\
\text { near by. }\end{array}$ \\
\hline Arucha & Prunus communis Hudson. & Small tree of Rosaceae & $\begin{array}{l}\text { Fruits sweet and sour } \\
\text { (Pinkish and white type of } \\
\text { arucha), White } \\
\text { producing smooth walled } \\
\text { fruits is edible and used for } \\
\text { making jam/jelly etc. }\end{array}$ \\
\hline Arupate & Prunus nepalensis (Ser) Stendel & Tree of Rosaceae & Yields edible fruits \\
\hline Aselu & Rubus diffusa Focke & Scrambler of Rosaceae & Medicinal \\
\hline Bandakopi & $\begin{array}{l}\text { Brassica oleracea L. var. capitata f. } \\
\text { Alba. }\end{array}$ & Brassicaceae & Vegetable used locally \\
\hline $\begin{array}{l}\text { Bandrey/Ramphal/ } \\
\text { Gante }\end{array}$ & Gynocardia odorata R. Br. & Tree of Flacourtiaceae & Medicinal plant \\
\hline Banmara/Kalijhar & Eupatorium adenophorum L. & Small shrub of Asteraceae & $\begin{array}{l}\text { Used to stop bleeding after } \\
\text { wound. }\end{array}$ \\
\hline Bans & Bambusa polymorpha Munro & Tree of Poaceae & Used to prepare Doko \\
\hline Bans-Choya & $\begin{array}{l}\text { Dendrocalamus hamiltonii var. } \\
\text { hamiltonii. }\end{array}$ & Poaceae & Used to prepare Doko \\
\hline Bans-Malingo & $\begin{array}{l}\text { Sinarundinaria maling (Gamble) } \\
\text { C.S.Chao \&Renvoize }\end{array}$ & Poaceae & Sticks in Gardens \\
\hline Bans-Parang & $\begin{array}{ll}\text { Sinarundinaria hookariana } & \text { (Munro) } \\
\text { C.S.Chao \&Renvoize } & \end{array}$ & Poaceae & Used to prepare "Doko" \\
\hline Bans-Paryang/Gopi & Cephalostachyum capitatum Munro & Shrub of Poaceae & $\begin{array}{l}\text { Used for various purpose } \\
\text { particularly for fencing. }\end{array}$ \\
\hline Bara Alainchi & Amomum subulatum Roxb. & Zingiberaceae & Economic and export one \\
\hline Behera Kapasi & Salix daltoniana Anders. & Small tree of Salicaceae & Fuel wood purpose \\
\hline Bhakate & Citrus grandis $\mathrm{L}$. & Rutaceae & $\begin{array}{l}\text { Ethno-botanically used as } \\
\text { medicine. }\end{array}$ \\
\hline Bhangra Junga & Urtica parviflora Roxb. & Urticaceae & $\begin{array}{l}\text { Flowers are edible } \\
\text { (Inflorescence), medicinal for } \\
\text { the remedy for arthritis. }\end{array}$ \\
\hline Bhangra Sishnu & Girardiana palmata Forsk. & Shrub of Urticaceae & $\begin{array}{l}\text { Outside the house i.e. near } \\
\text { then jungle. }\end{array}$ \\
\hline Bhokote & Hydrangea robusta HK.f. & Saxifragaceae & Small tree near jungle. \\
\hline Bhotay Pan & Rubus moluccanus L. & Rosaceae & Medicinal plant. \\
\hline Bilaune & Macropanax undulatum Seem & Araliaceae & Tree of forest. \\
\hline Bilon/Arupate & $\begin{array}{l}\text { Prunus nepaulensis } \\
\text { (Ser) Stendel }\end{array}$ & Tree of Rosaceae & $\begin{array}{l}3 \text { or } 7 \text { "Munta" used for } \\
\text { Jharphuck to release the pain } \\
\text { from body with the help of a }\end{array}$ \\
\hline
\end{tabular}


An Ecological Journey To Pandam Through...

\begin{tabular}{|c|c|c|c|}
\hline & & & local stone. \\
\hline Burbee & Solanum verbascifolium $\mathrm{L}$. & Tree of Solanaceae & Old tree near roadside. \\
\hline Chilaune/Aule & Schima wallichii Chois & Theaceae & Tree of Hill forest. \\
\hline Chulasi & Osbeckia crinita Benth. & Melastomaceae & Shrubs of Jungle. \\
\hline Chutro/Kesari & Mahonia acanthifolia G. Don. & Tree of Berberidaceae & Small tree in hill slopes. \\
\hline Dalne Katus/Aulay & Castanopsis indica A. DC. & Tree of Fagaceae & Wood for fuel. \\
\hline Dangre Bet & Calamus leptospadix Griff. & Climber of Arecaceae & Used to prepare Dokri \\
\hline Dhungri Phul & $\begin{array}{l}\text { Erigeron bellidioides } \\
\text { Clarke }\end{array}$ & Asteraceae & Not known \\
\hline Dhupi & Cryptomeria japonica (L.f.) D.Don. & Taxodiaceae & Planted \\
\hline Dudila & Ficus nemoralis Wall. & Small tree of Moraceae & Medicinal \\
\hline Faledo & Erythrena fusca Lour. & Fabaceae & $\begin{array}{l}\text { Young leaves are used as } \\
\text { vegetable. }\end{array}$ \\
\hline Fapar & Fagopyron esculentum Moench & Polygonaceae & Young leaves used as veg. \\
\hline Gharia Sisnu & Urtica dioica $\mathrm{L}$ & Urticaceae & Weed but use as Veg. \\
\hline Ghoge Chanp & Magnolia campbelii HK. f. & Magnoliaceae & Flowers may be White or Pink \\
\hline Ghurpis & Leucosceptrum canum Sm. & Lamiaceae & $\begin{array}{l}\text { Shade tree in Cardamom } \\
\text { garden. }\end{array}$ \\
\hline Gobrey Salla & Abies densa Griff. & Abietaceae & $\begin{array}{l}\text { Silver fir planted as } \\
\text { ornamental plant. }\end{array}$ \\
\hline Gogun & Saurauia napaulensis DC. & Actinidiaceae. & $\begin{array}{l}\text { Abundant Leafless fodder tree } \\
\text { also used as shade tree of } \\
\text { cardamom /elainchi garden }\end{array}$ \\
\hline Gokul dhup & Canarium sikkimense King. & Tree of Burseraceae & Not known, study required \\
\hline Gorundal & Passiflora edulis Sims & Climber of Passifloraceae & $\begin{array}{l}\text { In Kalimpong people making } \\
\text { juices, to prepare chutney and } \\
\text { jelly. }\end{array}$ \\
\hline Halhale & Rumex nepalensis Spreng & Polygonaceae & Medicinal \\
\hline Ikshu/Iskush/Ukhu & Saccharum officinarum L. & Poaceae & $\begin{array}{l}\text { Economic plant, Cultivated } \\
\text { inn a small scale in home } \\
\text { garden. }\end{array}$ \\
\hline Kaijal & Bischofia javanica Blume & Tree of Phyllanthaceae & $\begin{array}{l}\text { Invasive species, used in } \\
\text { Assam to identify Tiger by } \\
\text { Scratch-mark territory zone. }\end{array}$ \\
\hline Kalo Siris & Albizzia marginata Merr. & Mimosaceae & Wood \\
\hline $\begin{array}{l}\text { Kan chirle } \\
\text { ney/Silver fern }\end{array}$ & Cyathea dealbata (G. Forster) Swartz & Cyathaceae & Ornamental \\
\hline Kaneshi Lahara & Thunbergia coccinea Wall. & Climber of Acanthaceae & Weed. \\
\hline Kapasi & Acer campbelii HK.f. \& T. & Aceraceae & $\begin{array}{l}\text { Maple tree used for wood of } \\
\text { commerce. }\end{array}$ \\
\hline Katus & Castanopsis hystris A. DC. & Tree of Fagaceae & Edible fruits (Hajel Nut) \\
\hline Kaulo & Machilus villosa Hk.f. & Lauraceae & Use not Known \\
\hline Khanakpa & Evodia fraxinifolia Hook.f. & Tree of Rutaceae & Economic \\
\hline Labar & Ficus elastic Roxb. & Moraceae & Tree Planted \\
\hline Lali Guras & Rhododendron arboretum Sm. & Ericaceae & $\begin{array}{l}\text { Used by all local men and } \\
\text { women. If fish fin attached to } \\
\text { the inner throat, Flowers of } \\
\text { laliguras are to release the } \\
\text { fins. }\end{array}$ \\
\hline Lapche Kawla & Machilus edulis King. & Tree of Lauraceae & Edible fruits. \\
\hline Lati Mauwa & Glochidion assamica Hk.f. & $\begin{array}{ll}\text { Small tree } & \text { of } \\
\text { Euphorbiaceae } & \end{array}$ & Shrub of Jungle \\
\hline Maina Kath & Tetrameles nudiflora $\mathrm{R} . \mathrm{Br}$. & Datiscaceae & Tree \\
\hline Malata & Mallotus nepalensis Mell.-Arg. & Euphorbiaceae & Wood used as fuel \\
\hline Malta Tree & Macaranga gmelinifolia King. & Tree of Euphorbiaceae & Wood of Commerce \\
\hline Matane Phul & $\begin{array}{l}\text { Brugmansia suaveolens Berchst. \& J. } \\
\text { Presl }\end{array}$ & Solanaceae & $\begin{array}{l}\text { Small tree with pendent } \\
\text { flowers and fruits as } \\
\text { ornamental. }\end{array}$ \\
\hline Multa & Macaranga indica Wight. & Tree of Euphorbiaceae & Fuel wood plant. \\
\hline Narkat & $\begin{array}{l}\text { Saccharum narenga (Nees ex Steud.) } \\
\text { Wall. Ex. Hack. }\end{array}$ & Poaceae & $\begin{array}{l}\text { Fodder plant for cattle, used to } \\
\text { prepare Topri (Cap) }\end{array}$ \\
\hline Naspati & Pyrus communis L. & Tree of Rosaceae & $\begin{array}{l}\text { Found in Golai gaon and } \\
\text { Pandam Tea estate, as } \\
\text { medicinal fruits. }\end{array}$ \\
\hline
\end{tabular}


An Ecological Journey To Pandam Through...

\begin{tabular}{|c|c|c|c|}
\hline Nebara Phal & Ficus cunia Ham. & Tree of Moraceae & $\begin{array}{l}\text { Used as high } \text { Pressure } \\
\text { medicine. }\end{array}$ \\
\hline Nebara-Topri & Ficus racemosa L. (=F. glomerata Roxb.) & Tree of Moraceae & Medicinal plant \\
\hline Nebharo & Ficus roxburghii Wall. & Tree of Moraceae & Inflorescence is edible. \\
\hline Neebara & Ficus macrophylla Desf. Ex. Pers. & Ficus racemosa & Topri (Kancha) banay \\
\hline Nimi & Stephania glabra (Roxb.) Miers. & $\begin{array}{l}\text { Climber } \\
\text { Menispermaceae }\end{array}$ & Medicinal \\
\hline Oesalo & Rubus ellipticus Sm. & Rosaceae & Tasty fruits. \\
\hline Oiri & Oxyspora paniculata DC & Melastomataceae & Shrub in Shrubberies \\
\hline Okhar & Juglens regia L. & Juglandaceae & Edible fruit producing oil. \\
\hline $\begin{array}{l}\text { Pakhan } \quad \text { Bet } \\
(\text { Red/White)/Halka } \\
\text { nd }\end{array}$ & Bargenia cicliata (Haw.) Stemb. & Saxifragaceae & $\begin{array}{l}\text { Powder of leaves used to treat } \\
\text { the gonorrhea, Used to treat } \\
\text { the uterine bleeding of } \\
\text { women. }\end{array}$ \\
\hline Panchpati & Vitex heterophylla Roxb. & Tree of Verbenaceae & Medicinal \\
\hline Paniamla & Nephrolepis exaltat (L.) Schoott & Lomariopsidaceae & $\begin{array}{l}\text { Medicinal value, Used to treat } \\
\text { Urinary Trouble }\end{array}$ \\
\hline Pani-Saj & $\begin{array}{l}\text { Terminalia myriocarpa Heurck \& M. } \\
\text { Arg. }\end{array}$ & Combretaceae & Fruit medicinal \\
\hline Patle Kutus & Castanopsis tribuloides A. DC. & Tree of Fagaceae & Fuel and fodder \\
\hline Payun & Prunus serasoides D.Don. & $\begin{array}{l}\text { Rosaceae, } \\
\text { Biyete laga }\end{array}$ & $\begin{array}{l}\text { Used by Nepali, Tamang, } \\
\text { Chhetri, Kamidami tribes. } \\
\text { After marriage they used the } \\
\text { twigs with them and take } \\
\text { something as Viksha. }\end{array}$ \\
\hline Peepal & Ficus religiosa $\mathrm{L}$. & Moraceae & Religious plant \\
\hline Phaledo & Erythrena stricta Roxb. & Fabaceae & Fodder \\
\hline Phulkopi & Brassica oleracea L. var. botrytis L. & Brassicaceae & Vegetable \\
\hline Porka Siris & Albizzia lucida Benth. & Mimosaceae & Shade \\
\hline Pusse & Solanum trilobatum L. & Solanaceae & Halud paka phal \\
\hline Rahap & Raphidophora decursiva (Roxb.) Schott & $\begin{array}{l}\text { Evergreen climber of } \\
\text { Araceae }\end{array}$ & Ornamental \\
\hline Rangbhang & Caryota urens L. & Tree of Arecaceae & Edible fruits \\
\hline Rayo ko Sag & Brassica caularpa L. & Brassicaceae & $\begin{array}{l}\text { Vegetable and making edible } \\
\text { oil }\end{array}$ \\
\hline Rukhtomatao & Cyphomandra betacea Cav. & Solanaceae & Fuits used a vegetable. \\
\hline Saur & Betula cylindrostachys Wall. & Betulaceae & Used against Skin disease. \\
\hline Serialo & Brugmansia arborea (L.) Sweet & Solanaceae & $\begin{array}{l}\text { Shrubs/tree of Ornamental } \\
\text { kind }\end{array}$ \\
\hline Seto Chanp & Michelia doltsopa Buch.-Ham. Ex DC. & Magnoliaceae & Tree of jungle. \\
\hline $\begin{array}{l}\text { Siris tree } \text { Tea } \\
\text { Garden e }\end{array}$ & Albizzia procera Benth. & Mimosaceae & Shade tree \\
\hline Soura & Betula alnoides Ham. & Tree of Betulaceae & Wood of commerc. \\
\hline Sukhdarsan & Zantedeschia aethiopica (L.) Spreng. & Araceae & Ornamental everywhere \\
\hline Sunakhar & Cymbidium Swrtz & & Ornamental \\
\hline Sunakhari & Vanda undulata Lindl. & Orchidaceae & $\begin{array}{l}\text { Ornamental near the house of } \\
\text { some villagers. }\end{array}$ \\
\hline Teatey Champ & Michelia cathcartii Hk. F. \& T. & Magnoliaceae & Ornamental \\
\hline Thotne & Polygonum molle D. Don. & $\begin{array}{l}\text { Scandant shrub } \\
\text { Polygonaceae }\end{array}$ & $\begin{array}{l}\text { Ripe fruits used in Chutney. } \\
\text { Plant used as nice fodder for } \\
\text { cattle. Stem also used in } \\
\text { chutney. }\end{array}$ \\
\hline Titapati & Artimesia nilagirica (C. B. Clarke) Pamp & Shrub of Asteraceae & $\begin{array}{l}\text { Used to relief the ghostly } \\
\text { appearance (Tribal belief), } \\
\text { mostly used to reduce blood } \\
\text { pressure. }\end{array}$ \\
\hline Tooni & Toona ciliata M. Roem. & Meliaceae & Leaves are medicinal \\
\hline Trifole & Trifolium repens L. & Fabaceae & $\begin{array}{l}\text { White trifolium, if 4-leaflts } \\
\text { found, then person seems to be } \\
\text { lucky. }\end{array}$ \\
\hline Tulsi & Ocimum sanctum L. & Lamiaceae & Leaves used \\
\hline Utis & Alnus nepalensis D. Don. & Betulaceae & $\begin{array}{l}\text { Good timber for making } \\
\text { House in Hills }\end{array}$ \\
\hline
\end{tabular}


Notes: National flower of Nepal is "Lali guras" i.e. Rhododendron arboreum Smith, Munta i.e. Small twig, Jharphuck i.e. local belief about traditional practice by Janguru, Ojha, medicinemen, dabaimen, medical practitioner at local area.

As, per the study in northern and southern face of the Mulgaon forests, the important tree species found there are Moua (Engelhardia sp.) along with Laliguras ( Rhododendron sp.). The importance value index of Moua in northern face of the same hill slope is 110 whereas in the southern face it has its value 115 . The second dominant tree species, Laliguras with IVI value at northern face is 65 followed by 60 in southern face of the same hill with potential importance (Table 3 and 4). So, similarity Index (IS) of the tree species in between southern and northern is $88.8 \%$ (Table 5).

Table 3

Tree species of Mulgaon Forest with dominant tree species like Moua and Laliguras in 10x10m² ${ }^{2} \mathrm{uadrat}$ (Northern Face)

\begin{tabular}{|l|l|l|l|l|l|l|}
\hline $\begin{array}{l}\text { Sl. } \\
\text { No. }\end{array}$ & Name & RF & Rden & RDom & IVI & $\begin{array}{l}\text { Monitoring } \\
\text { Comment }\end{array}$ \\
\hline 1. & Alnus nepalensis & 10 & 10 & 5 & 25 & - \\
\hline 2. & Engelhardia sp. & 20 & 40 & 50 & 110 & Dominant sp. \\
\hline 3. & Erythrena stricta & 5 & 5 & 5 & 15 & - \\
\hline 4. & $\begin{array}{l}\text { Macaranga } \\
\text { gmelinifolia }\end{array}$ & 5 & 5 & 5 & 15 & - \\
\hline 5. & Mallotus nepalensis & 15 & 10 & 10 & 35 & Moderately \\
\hline 6. & Michelia cathcartii & 5 & 5 & 5 & 15 & - \\
\hline 7. & Rhododendron sp. & 30 & 20 & 15 & 65 & Dominant sp. \\
\hline 8. & Schima wallichii & 10 & 5 & 5 & 20 & - \\
\hline & Eight species : & & & & 300 & \\
\hline
\end{tabular}

Table 4

Tree species of Mulgaon Forest with dominant tree species like Moua and Laliguras in 10x10m² Quadrat (Southern Face)

\begin{tabular}{|l|l|l|l|l|l|l|}
\hline $\begin{array}{l}\text { Sl. } \\
\text { No. }\end{array}$ & Name & RF & Rden & RDom & IVI & $\begin{array}{l}\text { Monitoring } \\
\text { Comment }\end{array}$ \\
\hline 1. & Alnus nepalensis & 5 & 5 & 10 & 20 & - \\
\hline 2. & Engelhardtia sp. & 25 & 30 & 60 & 115 & Dominant sp. \\
\hline 3. & Erythrena stricta & 5 & 5 & 5 & 15 & - \\
\hline 4. & $\begin{array}{l}\text { Macaranga } \\
\text { gmelinifolia }\end{array}$ & 5 & 5 & 5 & 15 & - \\
\hline 5. & Mallotus nepalensis & 10 & 10 & 10 & 30 & Moderately \\
\hline 6. & Michelia cathcartii & 5 & 10 & 5 & 20 & - \\
\hline 7. & Rhododendron sp. & 20 & 5 & 15 & 60 & Dominant sp. \\
\hline 8. & Schima wallichii & 5 & 5 & 5 & 15 & - \\
\hline 9. & Betula cylindrostachys & 5 & 5 & 5 & 5 & - \\
\hline 10. & $\begin{array}{l}\text { Castanopsis } \\
\text { tribuloides }\end{array}$ & 5 & 5 & 5 & 5 & - \\
\hline & Ten tree species : & & & & 300 & \\
\hline
\end{tabular}

Diversity index of the tree species at the northern face in the same forest is 0.62 in comparison to the sothern face with value 0.68 . So, southern face is richer in tree species diversity (Table 5). Dominance Index of southern face $(0.88)$ is poorer than northern face (0.99). Evenness Index (e) of both the sites are similar, because both with 2 dominant tree species (Moua and Guras). Species richness index (d) of northern face is 2.83 whereas the value of southern face is 3.64, which is much higher than the northern. This indicates rigorous study of east and west face of hills along with different gradient through north and south face seasonally for herbs and shrubby vegetation also to draw a sharp line of decision about eco-degradataion.

Table 5

Phytodiversity indices of Tree species at Northern and Southern Hill face in Mulgaon Forests, Darjeeling.

\begin{tabular}{|c|c|c|}
\hline Indices & Mulgaon (North) & Mulgaon (South) \\
\hline
\end{tabular}


An Ecological Journey To Pandam Through...

\begin{tabular}{|l|c|c|}
\hline \multicolumn{1}{|c|}{-} & & \\
Diversity Index (H) & 0.62 & 0.68 \\
\hline Dominance Index (cd) & 0.99 & 0.88 \\
\hline Evenness Index (e) & 0.68 & 0.68 \\
\hline Species Richness Index (d) & 2.83 & 3.64 \\
\hline Similarity Index (IS) & \multicolumn{2}{|c|}{$88.8 \%$} \\
\hline
\end{tabular}

Social and cultural diversity of Darjeeling Himalaya is varied. It includes the ethno socio-culture of remote villages far away from the main township areas. Therefore, ethnicity and cultural believes also vary from site to site of the said area. All are grouped under the category as ethnic group. An ethnic group includes those people who possess some common cultural attributes such as language, norms and values, beliefs and folk practices, dress and food habitats, symbols and gestures, manners, rituals and customs etc. (Kurane, A., 1999). They may profess the same religion. Along with these cultural attributes they may have common descent or possess the same physiological characteristics. An ethnic group may live in a specific geographical area and have a common name. All these attributes bring homogeneity in the group which ultimately brings unity and integrity among the group members. These distinguishing physical and cultural features of an ethnic group make it unique, and distinguish it from other ethnic groups (Bhui, U., 2008-09). These ethnic groups usually have a sense of people hood, and to a certain degree many of the members of these groups believe themselves to be a nation. Thus these groups arise due to the feeling of loyalty to an ethnic group i.e. ethnic nationalism.

\section{Ethnic composition of Darjeeling Himalaya:}

The Nepali ethnic groups or the Gorkhas are found in a good number in Darjeeling districtand the adjacent duars region of jalpaiguri district of West Bengal (Bhui, 2008-09). But it is also a fact that their representation is not uniform throughout the districts. Darjeeling district is composed of four sub-divisionsDarjeeling Sadar, Kurseong, Kalimpong and Siliguri Sub-division. Among these sub-divisions, first three are largely populated by the Nepali ethnic groups, whereas the population composed of Siliguri sub-division is mixed type, made up of the Bengalis, Nepalis, Adivasis, Biharis and many other ethnic groups. The study area includes the groups which include the caste like-Mangar, Rai, Tamang, Bhutia, Sunar, Chettri, Cami, Damai, Gurung, Dami, Cami and Gurung etc.

\section{Agriculture and People:}

They planted crops of agricultural importance are different vegetables like Rai (member of Brassicaceae), Alu (Potato ), Muli (Member of Brassicaceae), Motor (Pisum sp.), Sevi-Sim (Legume as bean), etc., Fruits of commercial kinds found there are Naspati, Arucha, Ukhu (Saccharum officinarum). Some families use Cattle, Suar, Kukhra (Murgi), Bakhri etc. as domestic one. A kind of soil called Safed mati (White soil) available there as decorative agent for their common use. These are called Chullah mati or Pabitra mati (Sacred soil). Other places having less deposition of red soil called Lalmiti/Lalmati, used for the same purpose. Water available from source called Soch (leaching point from which small amount of water come out). Good examples are the places called "Basbote, Sourini, Kulungdara, Ardhure, Mulgaon, Cohukidar dara, Jowary basty and Limbu basty. All the points releasing water and collected in a big tank called Thumbi (Water supplying point) from which filtrated water goes to the village for domestic pupose.

\section{Bamboos and local Economy versus Ecology of Darjeeling Hill}

Bamboos are used for various purposes and its great versatility qualifies it to be a multiple use alternative to timber, food to the rural poor and tribal in particular (Tamang et al., 2013). According to the opinion of the authors, in Sikkim Himalaya people use a large number of species in various daily works associated with direct economy. In Darjeeling Himalaya the Bamboos have the same demand and have a large scope to develop market economy if put in a proper managerial way through research and development by Govt. and NGOs. The purposes they solve are given below:

1. Fodder purpose-Cattle use the leaves of bamboos. 2. Mat making purpose i.e. Chitra used to protect gardens along with poles of bamboos (fencing purposes), sometimes cover the roof of a house or hut; 3 . Big basket used to carry materials like tea leaves, meat, fishes, poultry materials, vegetables, fruits, straw, soil, garbage etc. The common name is "Doko" in Nepali; 4. Wrapping sapling in plantation sites or in plantation stand during afforestation programe; 5. Shelter for Chicks, ducks and hens even to small kids or puppy; 6 . Constructing house in village or in slums; 7. Supporting prayer flags in sacred places; 8. In garden as pillar to support weak vegetable plants; 9. Bamboo scaffolding; 10. As vegetable; 11. House gate, garden gate, fencing garden periphery etc., 12. Sticks for fishing purposes; 13. Sticks for various purpose in domestic way i.e. in house 
broom, shoot broom etc.; 14. For temporary use i.e. for the preparation of bridge or road on canals and creeks in remote village etc. So, there is a large scope to study and research on economy and ecology of Bamboos of Darjeeling Himalaya, because it can be used largely to prepare soft toys by Handicraft artists in Tourist area like Town Darjeeling. Therefore, employment of people of remote area may be made through the new horizon in Darjeeling in near future.

\section{Ethno-medicine and Ethno-culture:}

Saha et al. (2011) reported 78 species of plants which have immense effect on environment that have their antimicrobial as well as antioxidant activities. All the plant species belonging to 70 genera under 47 families of angiosperms and growing in the said habitat thoroughly but not restricted in a village or in a pocket. The present study is therefore a study which having a lot of 103 species in a small area having diverse potentiality of those plats with immense ecological role. Sharma (2013) studied on Ethnobotanical plants of Darjeeling Himalaya and documented 91 species under 53 families in Darjeeling Himalayas which have been extensively used by the local people for their skin diseases. All the plants are available in the premises of the said area with good potential as they are natural one. The potential use varies from site to site as because the cultural diversity is different.

\section{Tourism and Social development through eco-tourism in Darjeeling:}

Darjeeling Himalaya performing the function of eco-tourism which presents the issues related to the mass communication within the hills and some aspects pointing out the betterment of the situation, through sustainable tourism (Rohin, 2009). The present study has potentially fit to develop the eco-tourism in near future.

\section{Effectiveness Monitoring and Sustenance of Life:}

Effective monitoring address the question of how successful a project ultimately is at restoring the ecosystem or component parts. It involves assessing restoration progress in relation to initial objectives, and refining treatment prescriptions, where required, to increase their effectiveness (Anonymous, 2002). Vegetation and soil may be used in the selected site to monitor the forest and people for eco-monitoring purpose round the year.

\section{Need setup of Nursery and Sancturay for potentially well developed Laliguras:}

Rhododendrons are the national flower of Nepal. Government of Sikkim has established two Rhododendron Sanctuaries (Singba and Barsey) for the conservation Rhododendrons and popularizes the species among people (Singh et al., 2003; Tiwari et al., 2006 and Singh, 2009). To date no conservation measures have been initiated by authority of Darjeeling Himalaya including Botanical Survey of India, for habitat concerned conservation in the same area which are going threat under manmade as well as natural causes. So, the present site may be the habitat for conservation of Rhododendron in near future. Even ecomodeling may be made there. Some authors suggested "Ecological niche modeling" which can thus save an important role in various in-situ as well as ex-situ measures for establishment of arboreta, sanctuaries, park and avenue, forests protected areas through community management, botanical gardens and also for in-vitro research activities for species conservation (Menon et al., 2012). Mulgaon and Golagaon may be the sites for the same in near future.

\section{FIGURES IN PHOTO PLATES (1-13)}

\section{Plate-1}
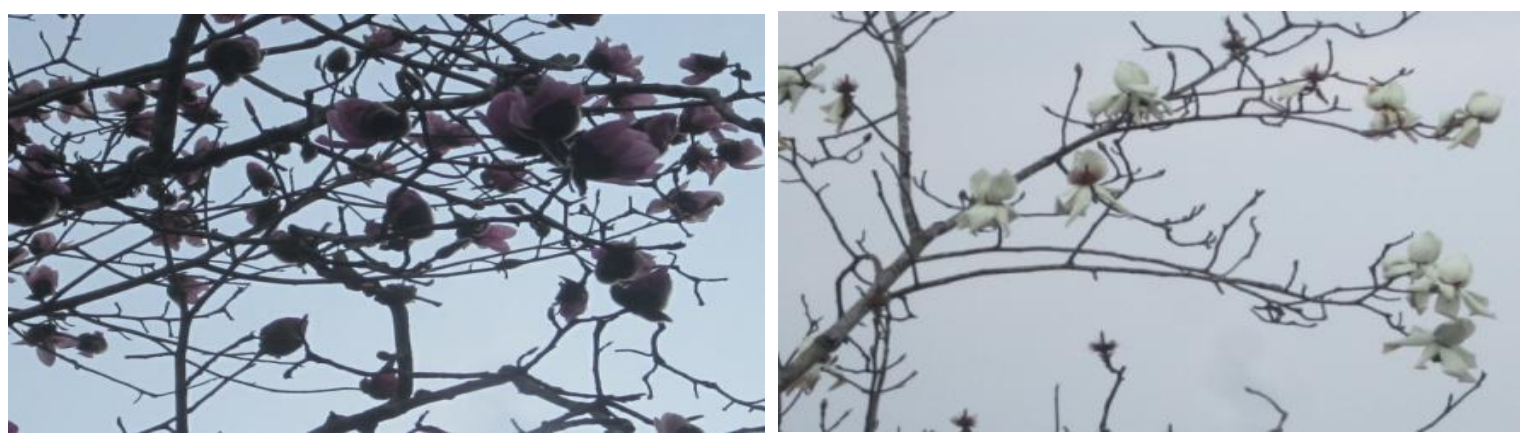


\section{PHOTO PLATE -1}

Figures 1-2: At the left pink Magnolia campbellii Hook. f. \& Thoms. and at the right white Magnolia campbellii (Planted form) are in blooming stage along the road and way to Pandam, Udaygram, Darjeeling, West Bengal, India, with magnificent beauty of nature during late February to March (Photo by Dr. D. Das). Note that white coloured flowers having pleasant smell (Source: Divya Pradhan, a student of UG Deptt. Of Botany, Darjeeling Govt. College: Cell-091-09635741164).
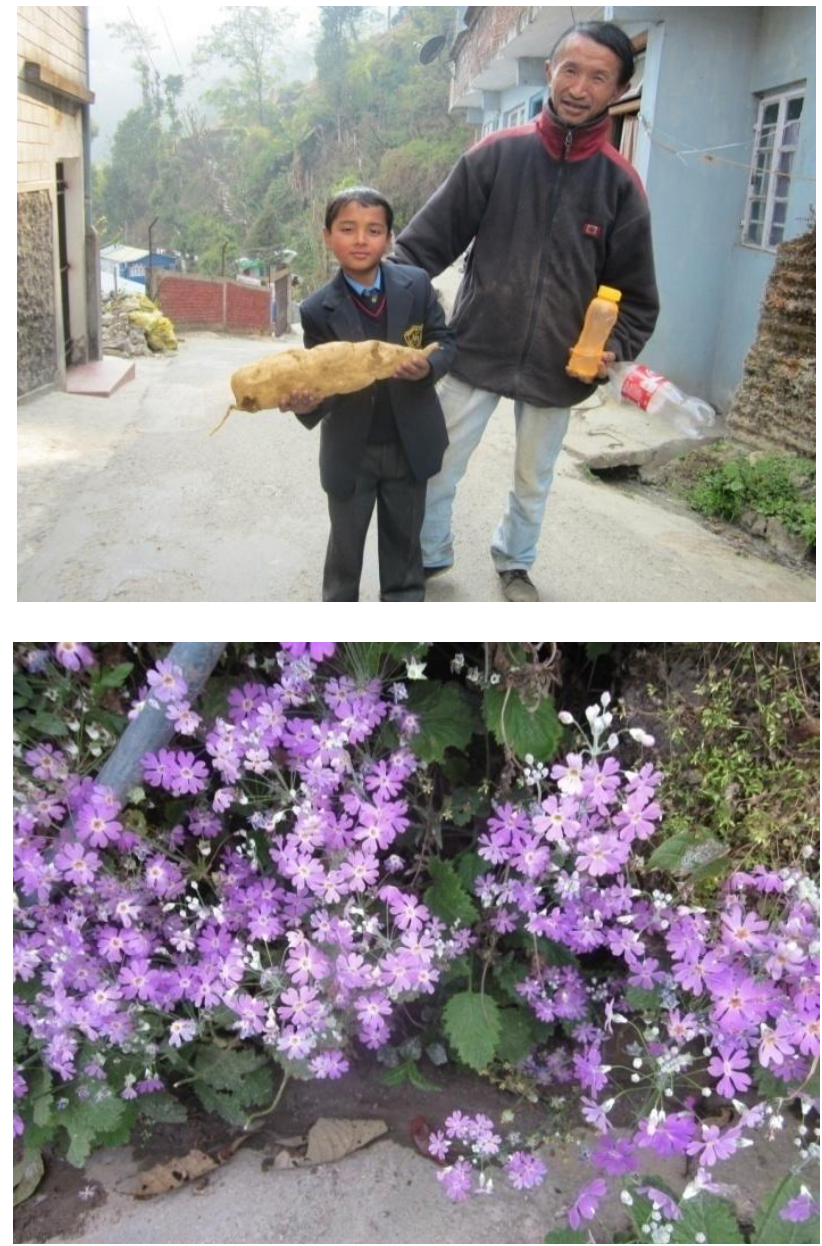

Figures 3-4: Eskusgh-ka-Jara (Tuberous root of Sechium edule (Jacq.) Swartz.-a unique vegetable for local people at Darjeeling, West Bengal at the upper and Primula melacoides in roadside of Pandam Village, Darjeeling at the lower.

PHOTO PLATE -2 

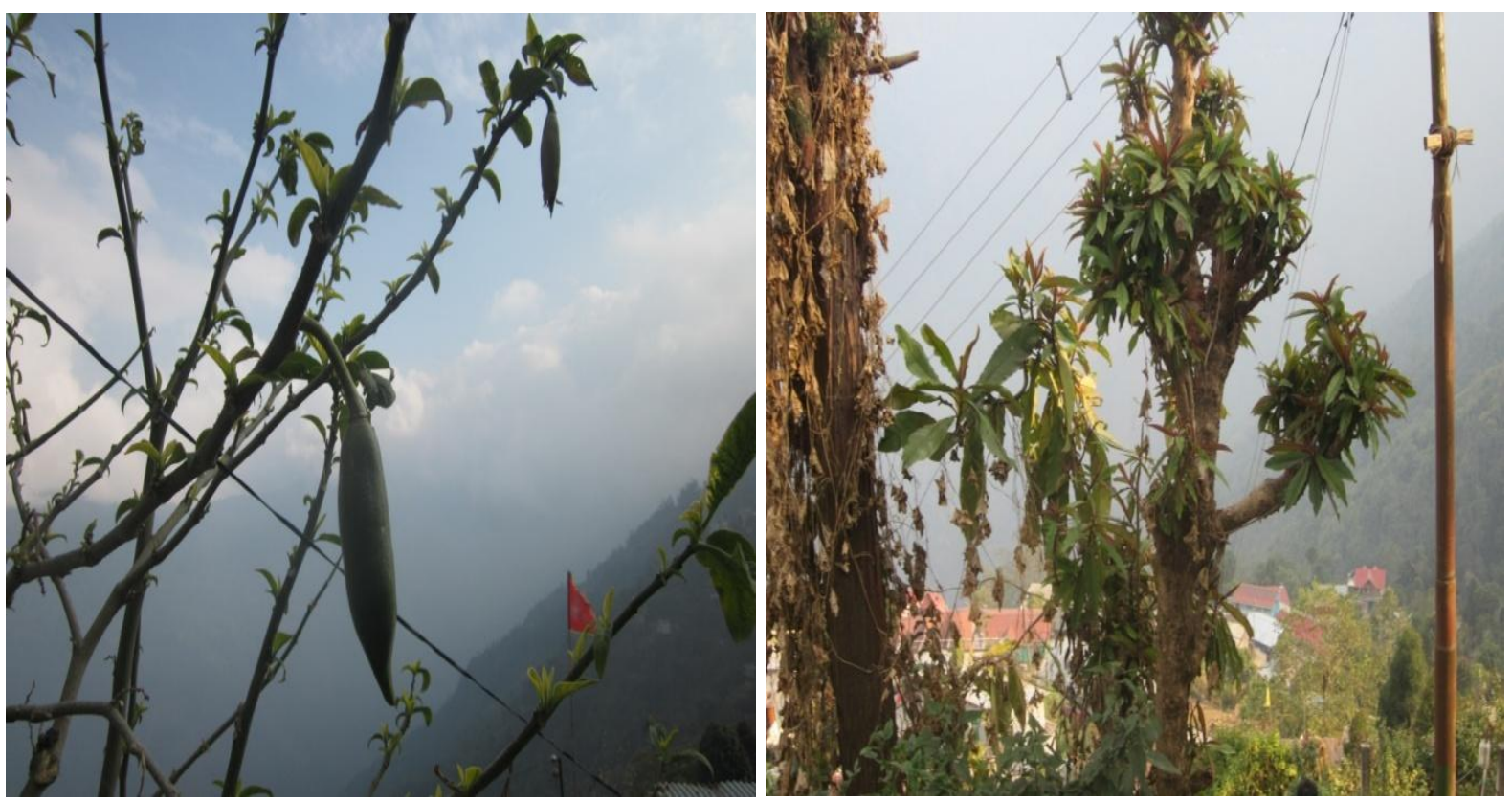

Figures 5-6: Fruit bearing Solanaceous Trumpet tree (Brugmansia suaveolens Berchst. \& J. Presl) at left and Gagun tree (Saurauia napaulensis DC. ) as a fodder tree at the right.
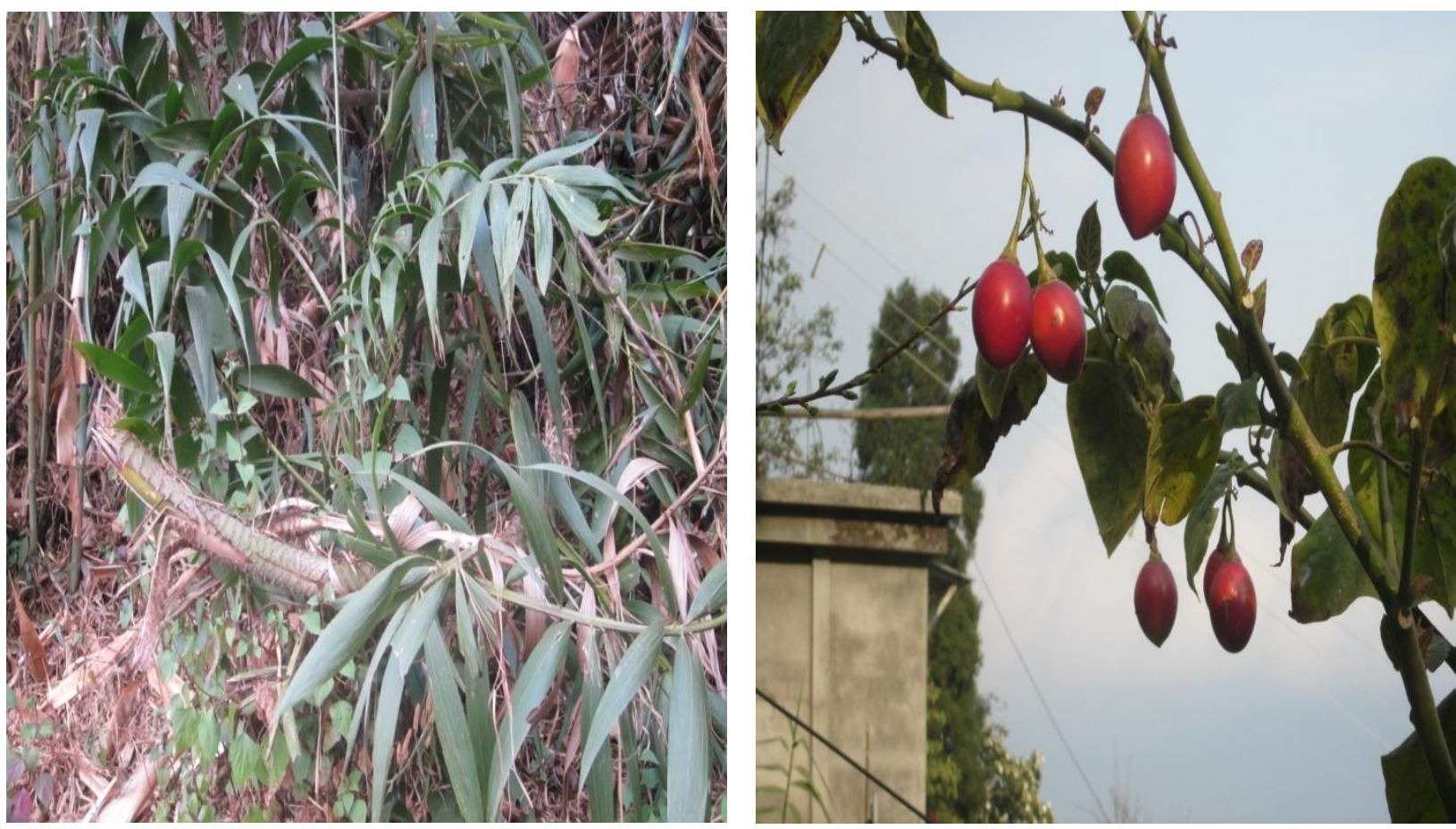

Figures 7-8: Cyphomandra betacea Cav. (Rukh Tamato of Solanaceae) fruits in a local Home garden at Udaygram, Darjeeling in the left and Calamus sp. (Arecacea) at the right.

PHOTO PLATE -3 


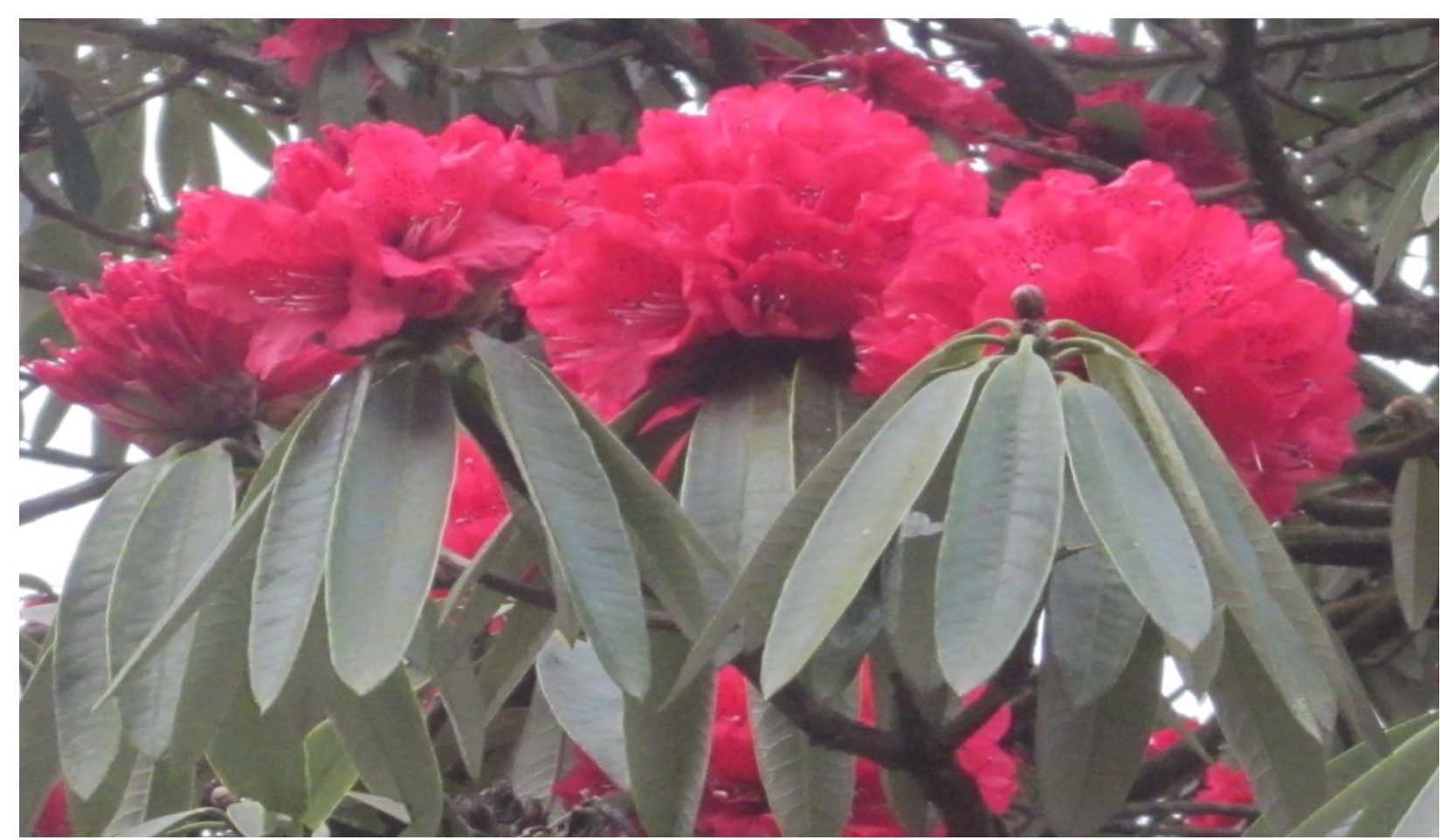

Figure 9: Rhododendron arboreum Smith (Lali Guras) blooming in stage at Pandam, Darjeeling.

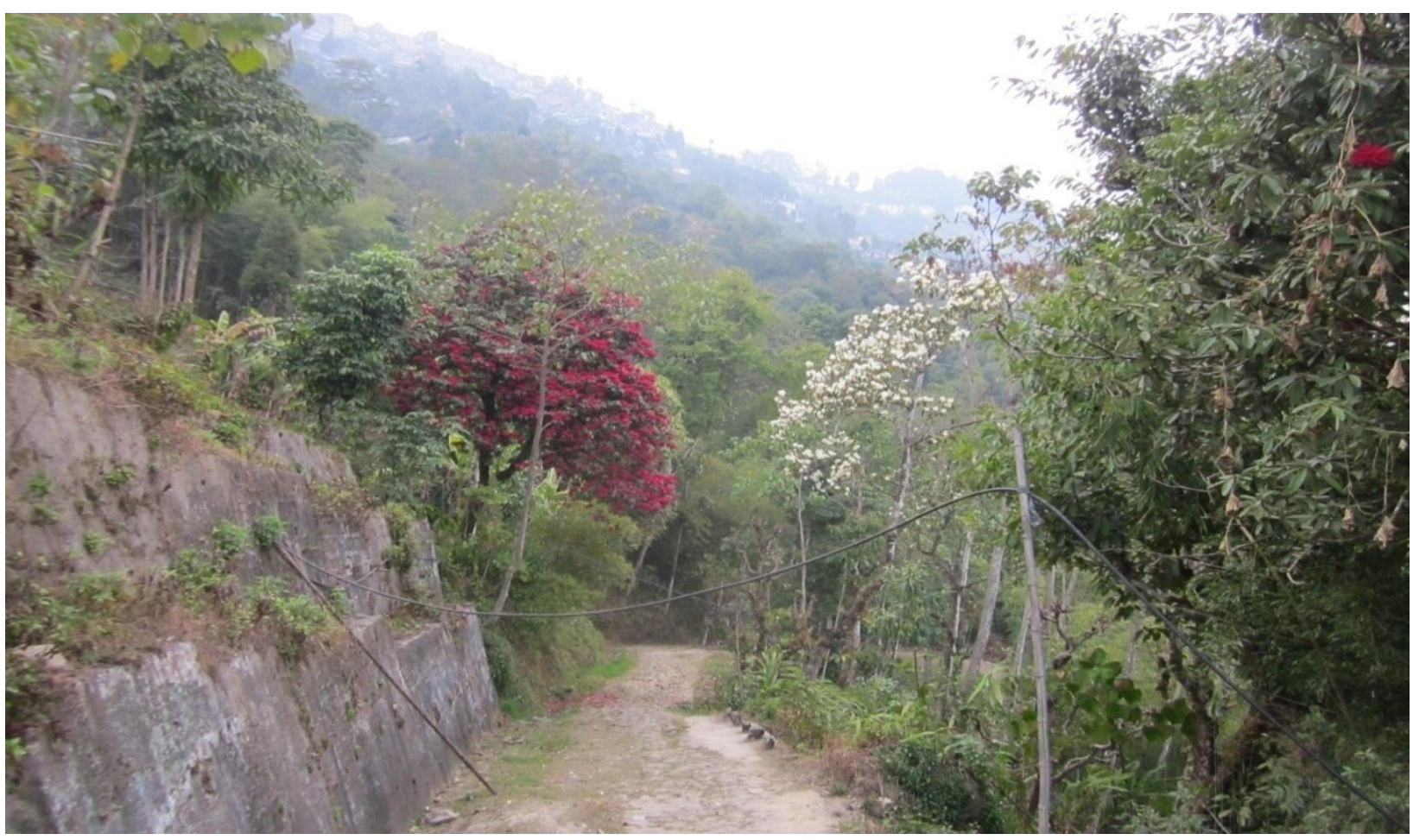

Figure 10: Left hand side of photograph showing Lali Guras (Rhododendron arboreum) and Right hand side showing White Champ (Michelia cathcartii) along the slopes of hill towards Pandam, Darjeeling during late monsoon (Photo taken by Author on 06.03.2014)

PHOTO PLATE -4 

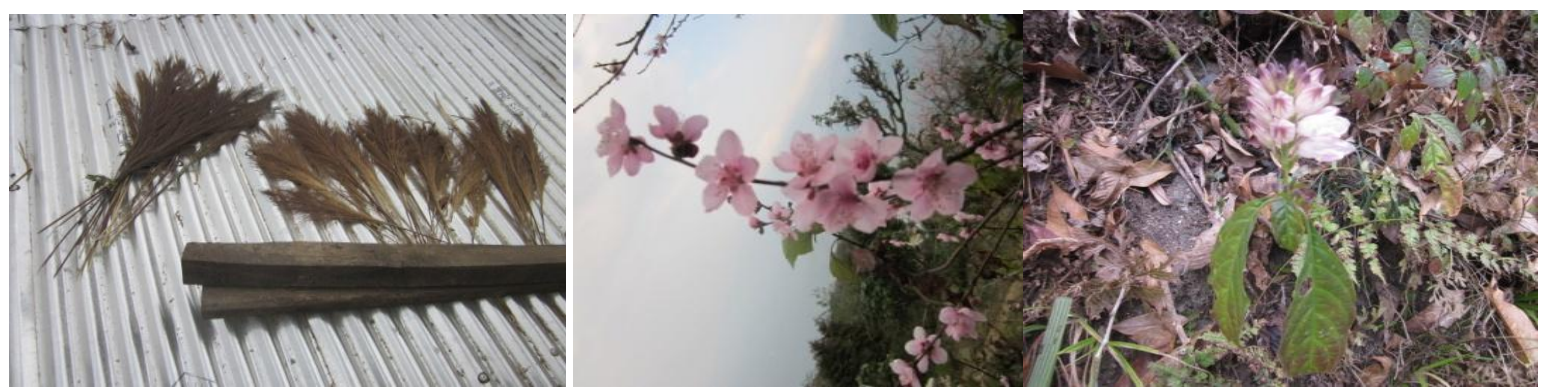

Figures 11-13: Drying flowering scapes of Thysalolaena maxima (Roxb.) O. Kuntz.(Left), Arucha: Prunus sp. (Middle) and Asystacia macrocarpa Nees of Acanthaceae (Right) showing flowering during monsoon at Jungle path of Pandam, Darjeeling, West Bengal, India.
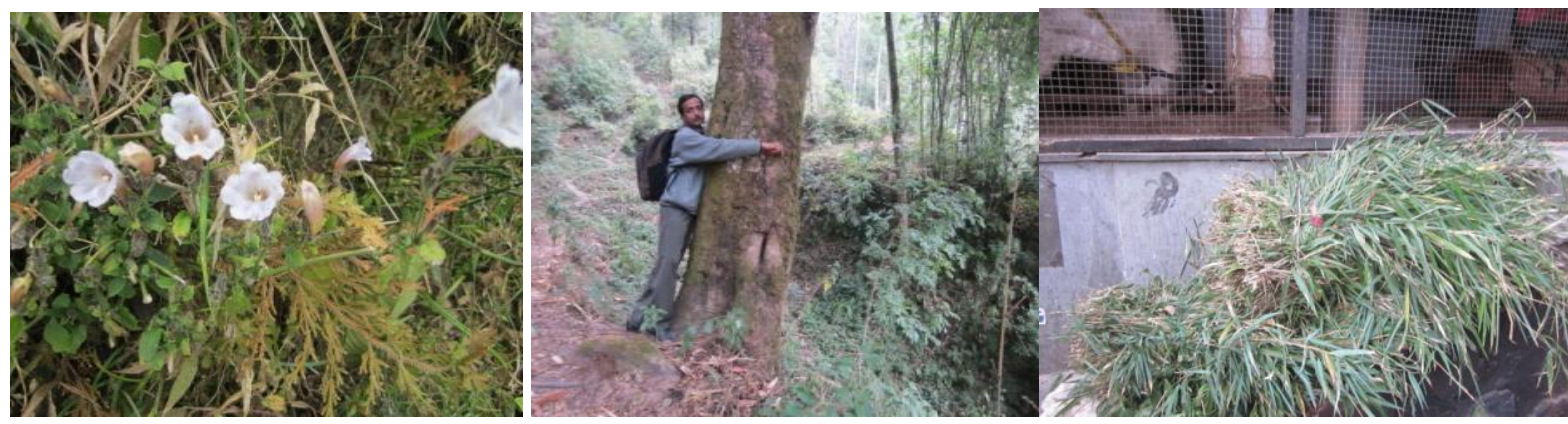

Figures 14-16: Goldfusia pentastemonoides Nees of Acanthaceae indicating village nearby as indicator species (Left); Author measuring GBH (Girth at breast Height) of Moua tree (Engelhardia spicata) at forest of Mulgaon (Photo by B.P. Sharma of Mulgaon) at the middle; The fodder part of Bamboos is deposited in front of Stable near Chowrasta (Centre of four ways) is collected from Bamboo thicket. 


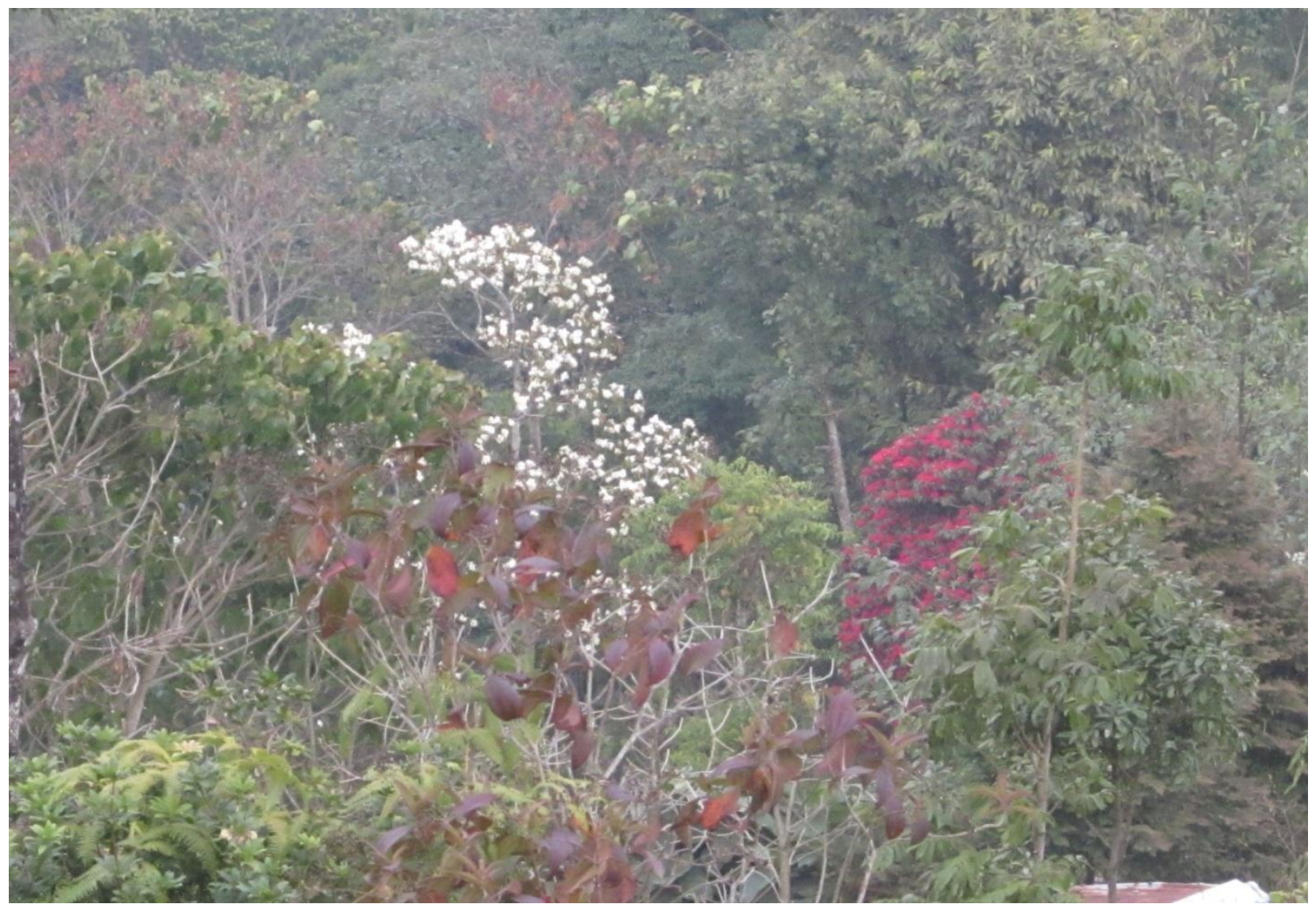

PHOTO PLATE -5

Figure 17 Mixed heterogeneous vegetation reaching Climax formation at jungle of Pandam from Udaygram, Darjeeling; red colored leaves indicating the plant like Oxyspora paniculata DC. with dried fruits, white flowers for Michelia sp. (Champ) and red for Rhododendron sp.(Lali Guras) flowers. (Photo by Dr. Debabrata Das, Asst. Professor of Botany, Post of Graduate Department of Botany, Darjeeling Govt. College, Darjeeling, West Bengal, India)

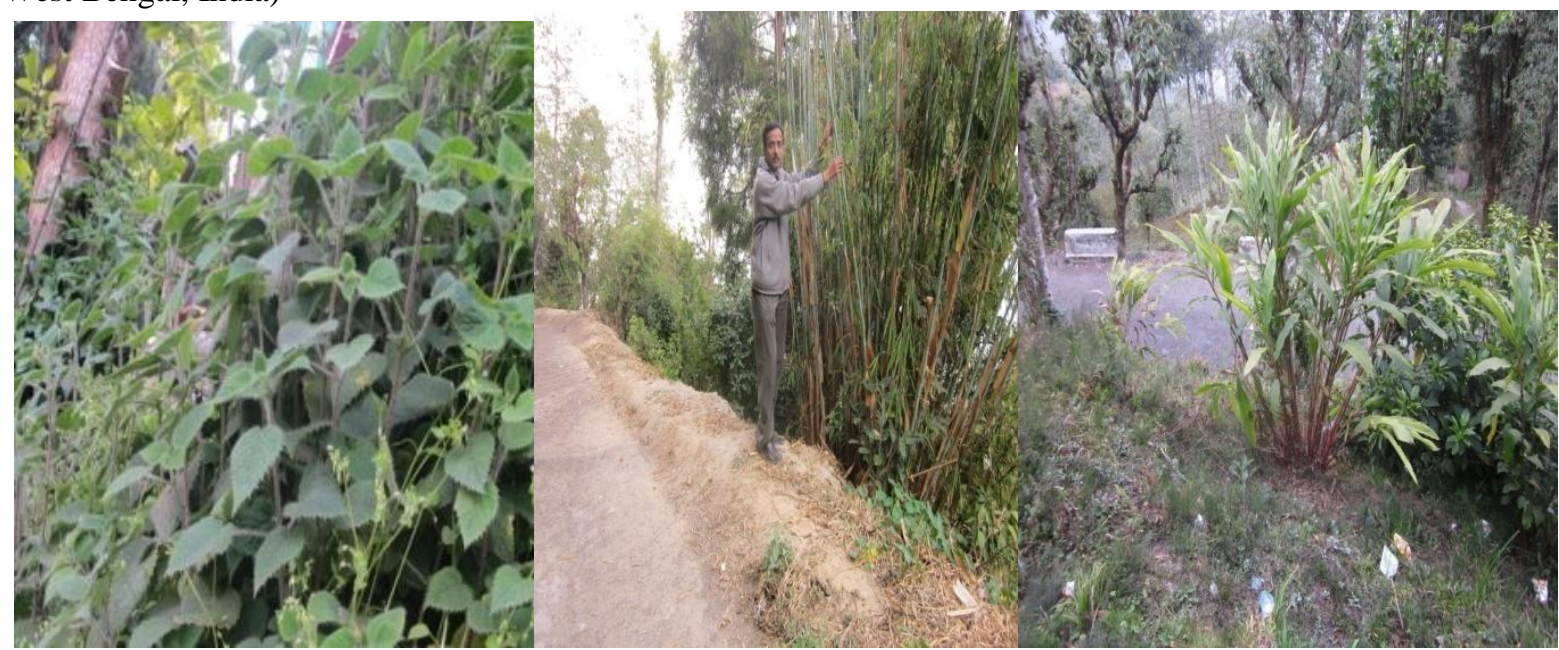

Figures 18-20: Gharia Sishnu (Gharia means near House) at the left, Mali Bamboo (middle) and Amomum subulatum (Baro Alaichi) at the right.

PHOTO PLATE -6 

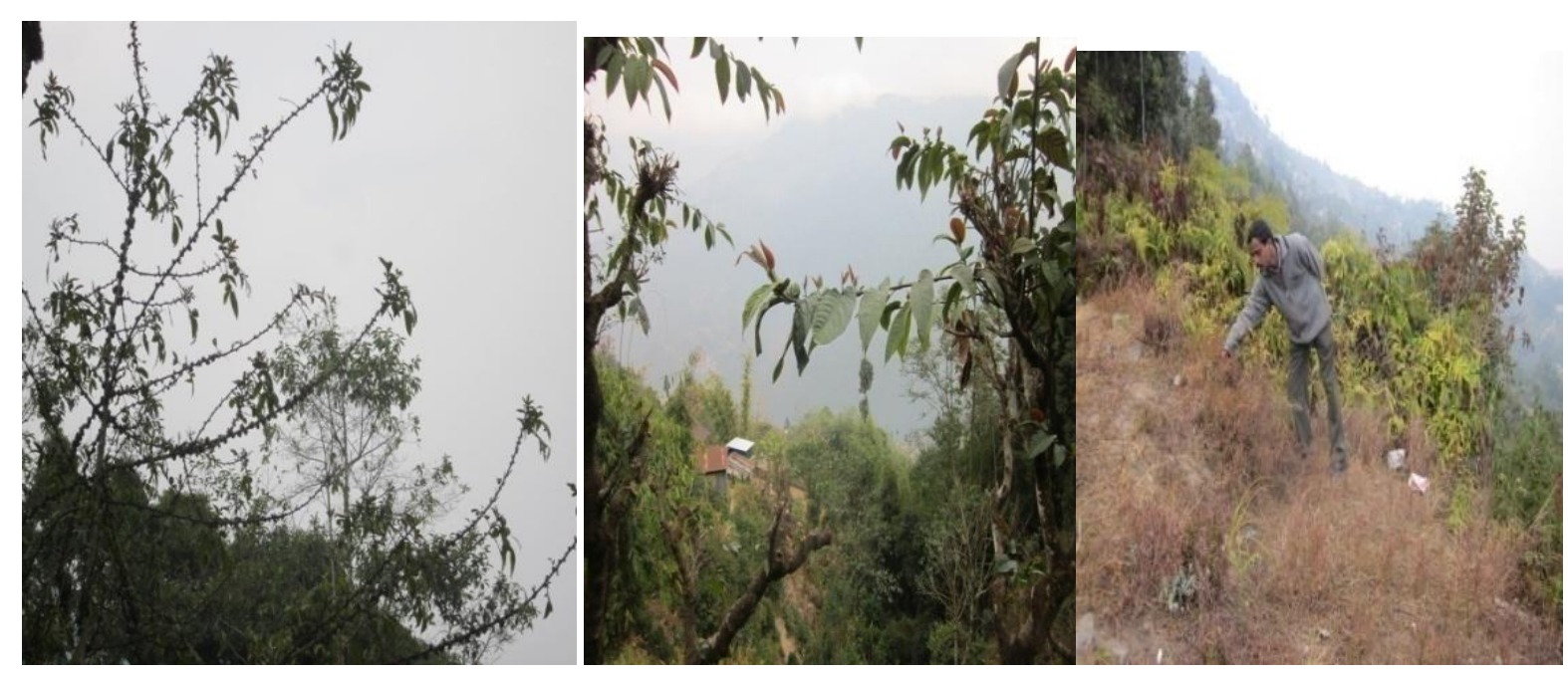

Figures 21-23: Bokey Timbur plant-Zanthozyllum sp. (Seeds used as condiments like Hing i.e. Ferula sp.), Ficus semicordata (Khanew) and Author collecting Seeds of some medicinal herbs during field visit (Photo by Kamal Kanta Roy, Non-teaching Staff of Zoology Department, Darjeeling Govt. College), Note that in Nepali word "Bokey" means Male Goat.
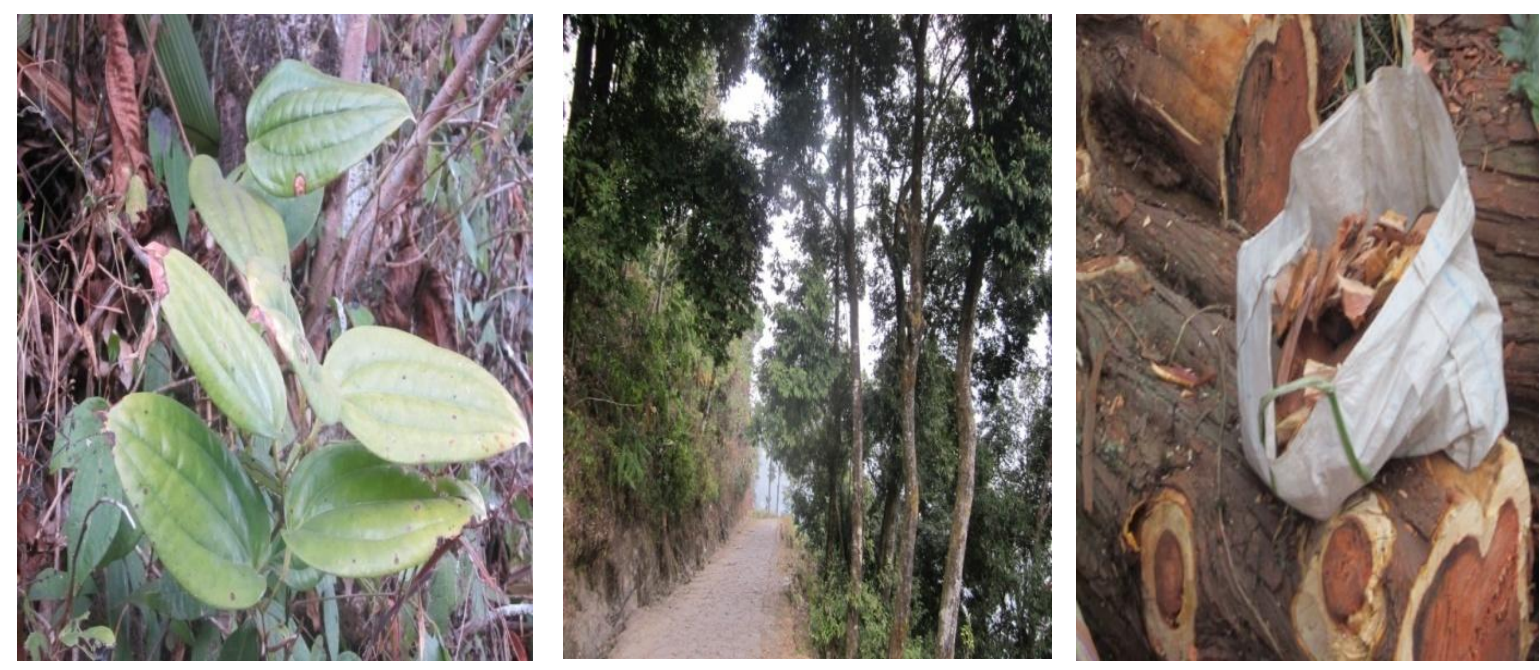

Figures: 24-26: Smilax ferox Wallich ex Kunth (Smilacaceae) at left, Trees of Engelhardia spicata Leschen. Ex Blume (Juglandaceae) at middle and Felled tree Cryptomeria japonina ( Salla Dhupi) at right.

PHOTO PLATE - 7 

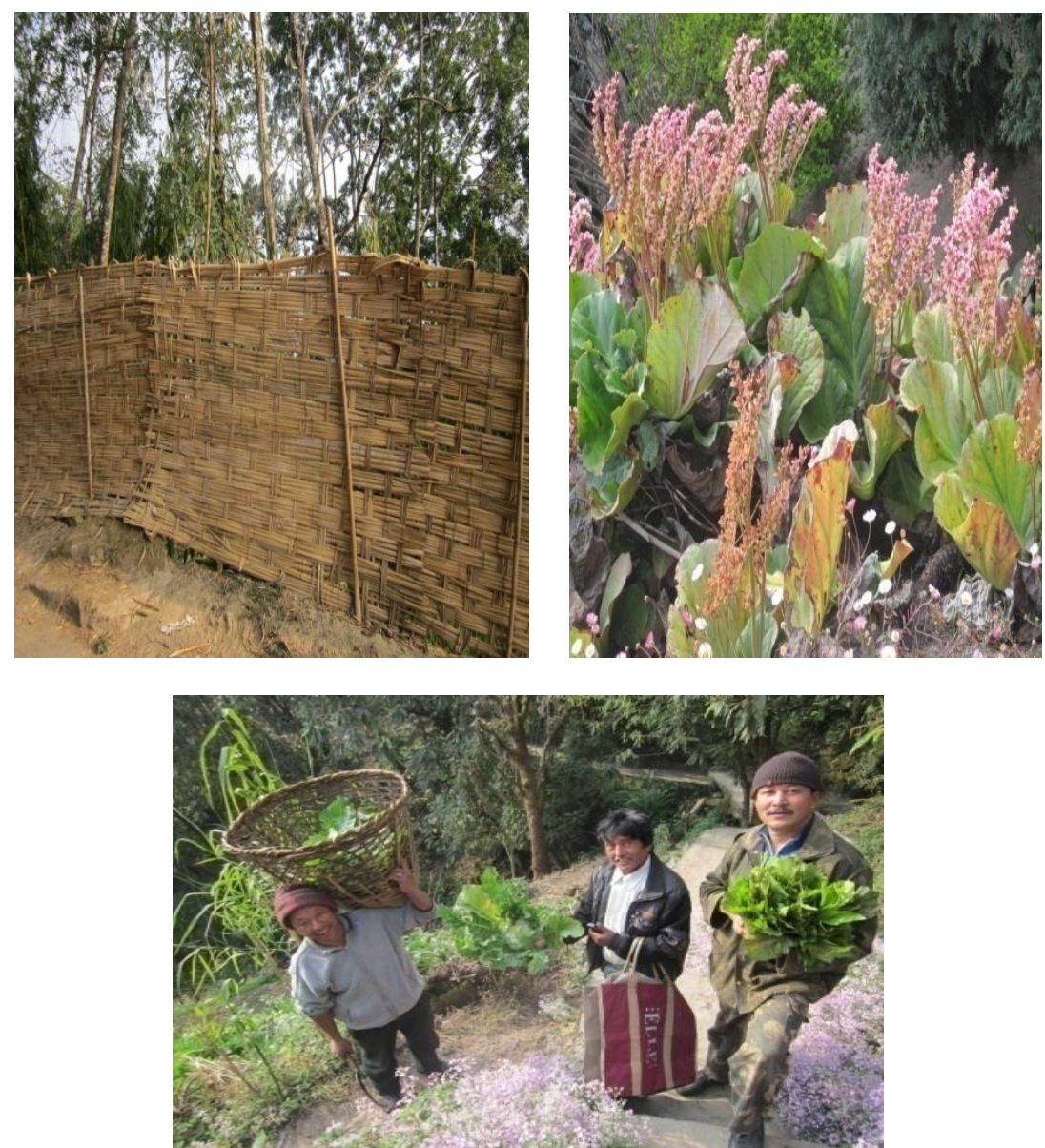

Figures 27-29 : Chitra i.e. covering made by Bhalu Bans, Pakhan bet and Vegetables collected from local garden at Golao gaon by Doko (Container/Basket made up of Bamboos), Darjeeling. Note that basket without holes are called Thumpsey/Tokri also used for the collection of tea leaves in garden and with holes is called Doco (Collection of fodder plants, wood, building materials etc.) at upper left. Pakahn bet locally used to relief the throat pain (Dried roots as whole and greens leaves without fabricated lamina) at the upper right. Vegetables collected by Golaigaon villagers at the bottom. Person at middle is resource person.
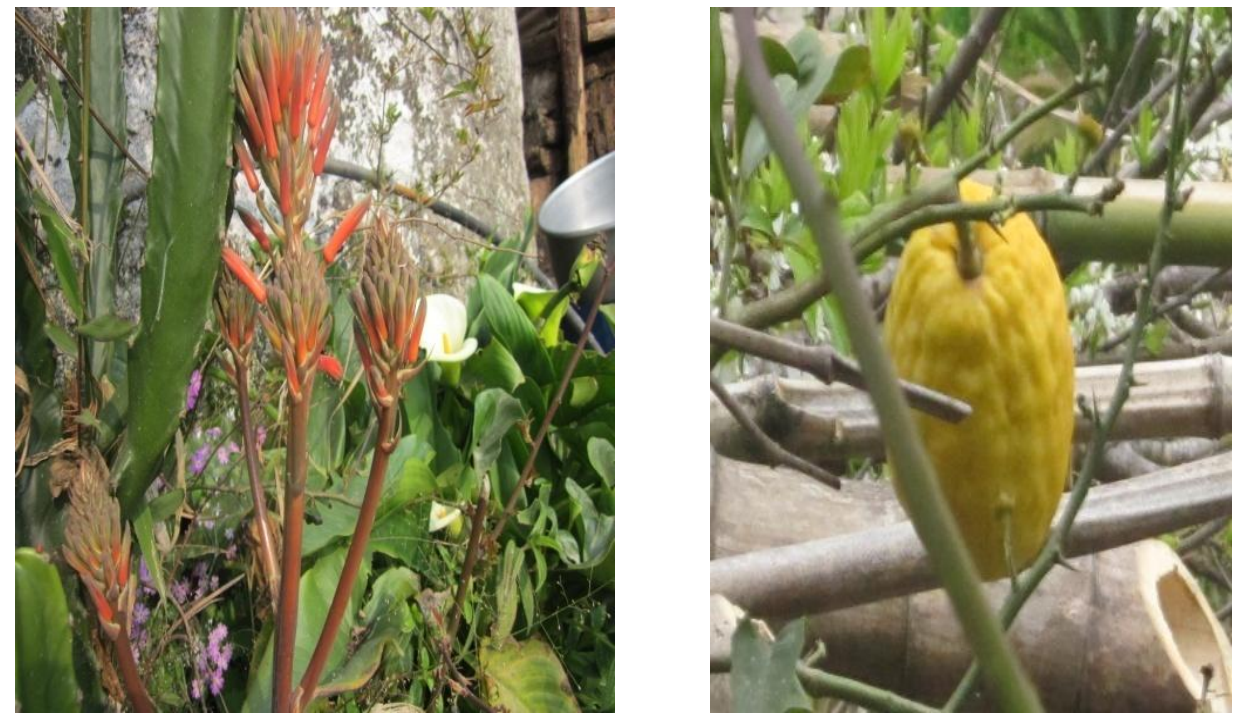


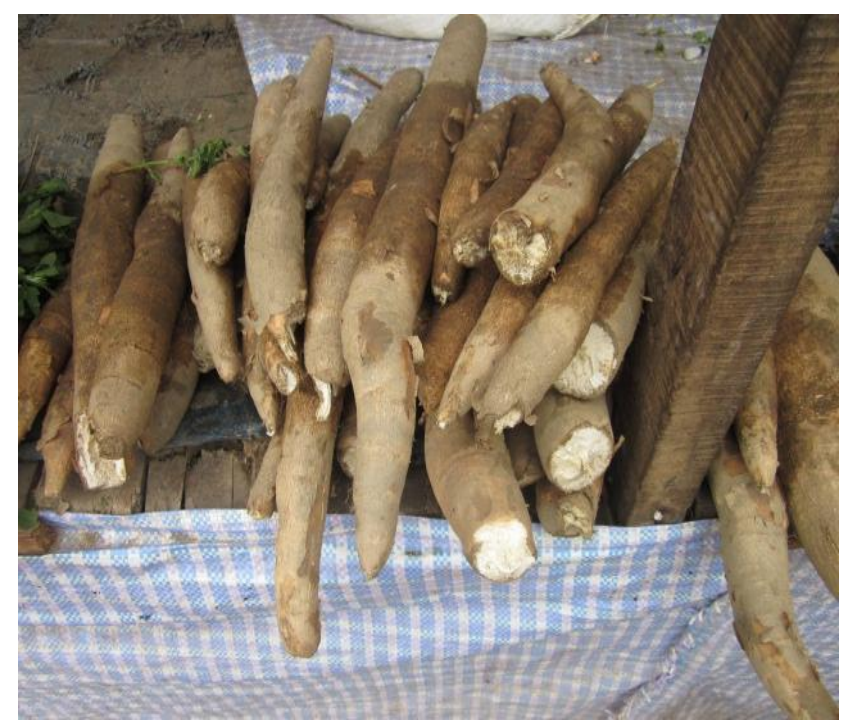

Figures 30-32 : 30. Orange-red coloured flowers-scape of Aloe sp. (A. striata x maculata hybrid), WhiteSukhdarsan; 31. Bhokatay fruit-Citrus grandis L. (Juice of fruits used for drinking purpose, very rich in Vitamin-C) and 32. Simal (Manihot utilissima Pohl. of Euphorbiaceae). Note that, modified stems of different creepers are called "tarul".

PHOTO PLATE- 8
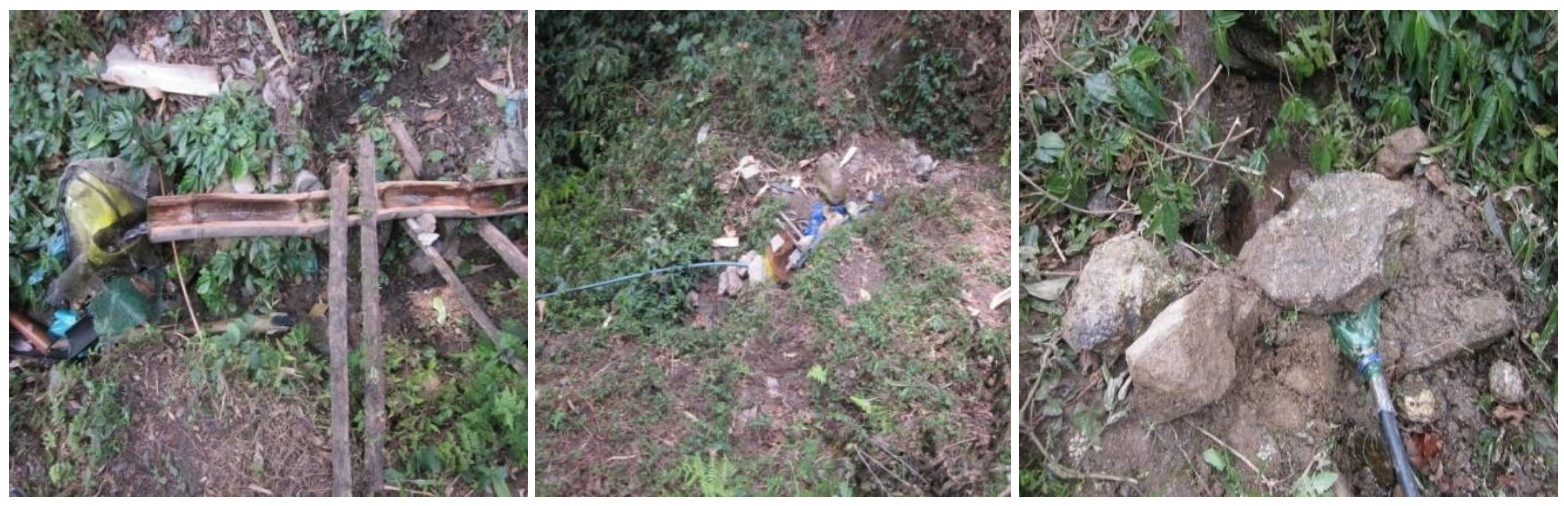

Figures: 33 (a, b, c) : Local technique to carry water from Source so called "kua or muhan" by which water is being collected to a big container called Thumbhi (Large reservoir) and from there water supplied to Village via a pipeline for a kilometer or more to carry water by the help of pillars of Trees in the hill slopes. First figure indicates Thumbi, second and third figure for kua. Note that bamboos (half pipe) are used to carry water from Hills. 


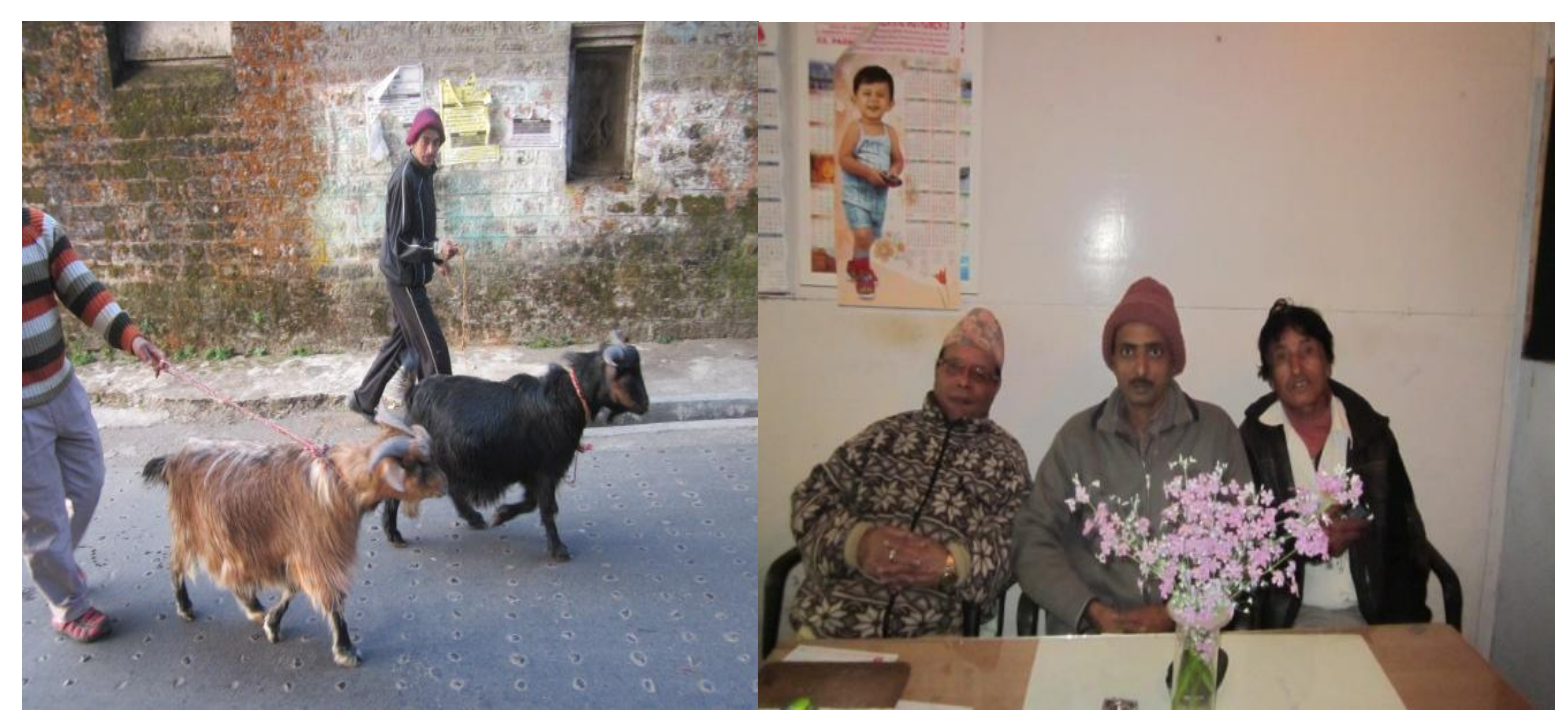

Figures 34-35: 34. Himalayan Goats used for meat production (Left), 35. Dhan Kumar Chhetri (Left), AuthorDr. Debabrata Das ( Middle) and Bishnu Prasad Sharma (Right) as resource person and field man at Botany Department of Darjeeling Govt. College after discussion about common Problems of Himalayan People in a day, note that flowers are Primula sp. (Primulaceae) of Eastern Himalaya, Darjeeling as wild.
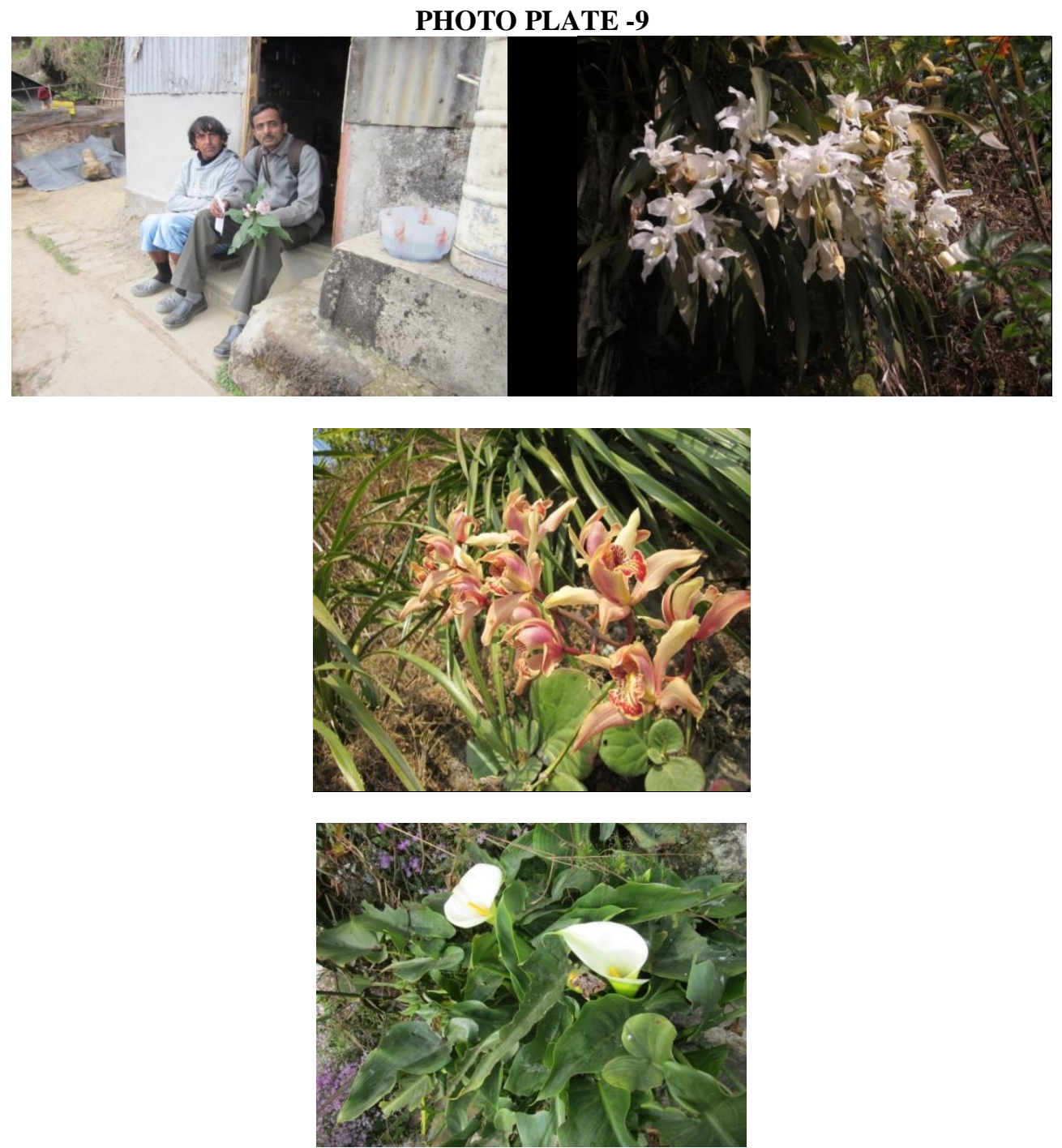

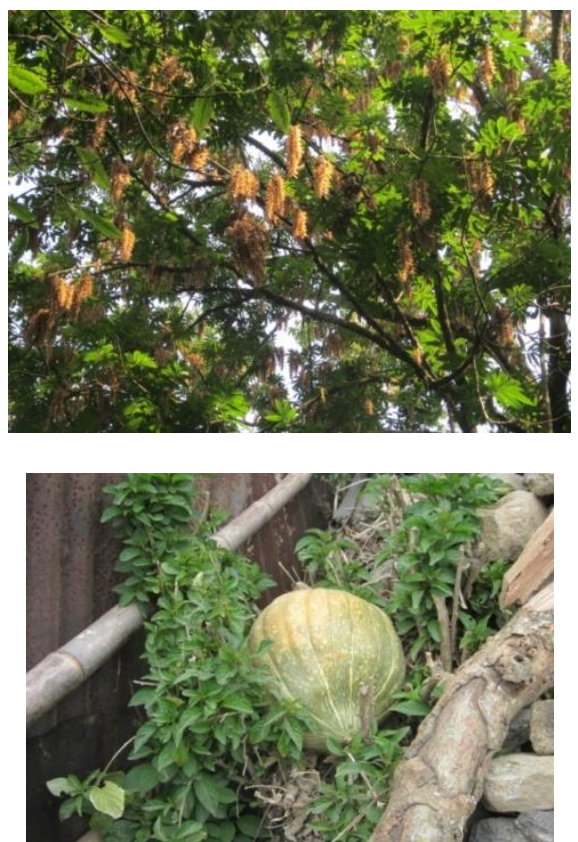

Figures 36-41: Author and villager (Left) at Mulgaon (Photo by Mr. Bishnu Prasad Sharma of Mulgaon Village), Colegyne cristata Lindley (=C. nitida Lindey) locally called Sunakhara-a white wild Orchid; Cymbidium sp. (Orchid) along with small Pakhan bet (Herb), Sukadarsan (Plant of Araceae), Pendent fruits of Engelhardia spicata (Moua/Simkukra) tree at fruiting stage, Farsi i.e. Cucurbita pepo L. (A kind of Pumpkin called summer squash) in the same village . Note that the "Farsi" fruit is used as edible vegetables making sweets and Halua (Like Suji with sugar). Big yellow flowers are used to prepare Pakoda/Pakora with (Bason fried form). Tendrils are used as vegetables.
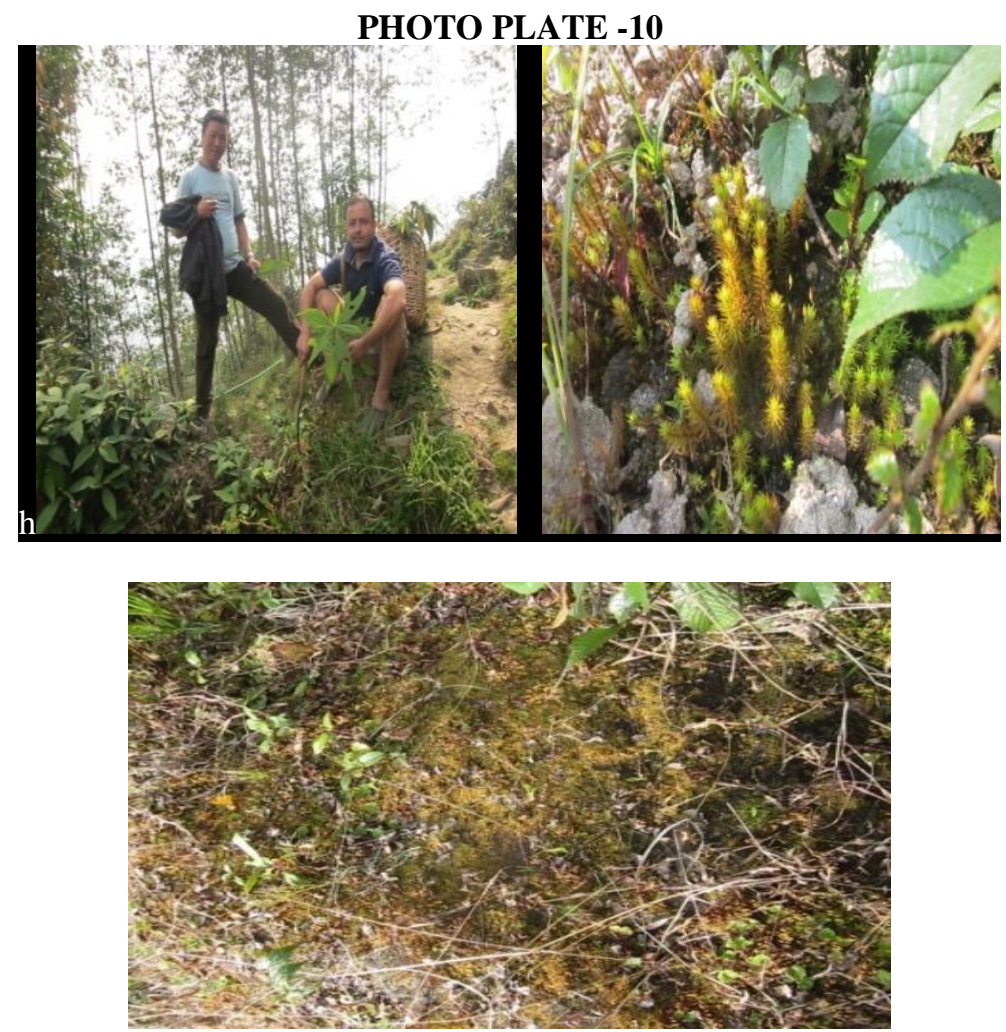

Figures 42-44: People collecting fodder for Cattle, mainly Thotne plant i.e Polygonum molle D. Don. Fodder plant giving shade to moss plants, note that erect plants are male plants of Polytrchum sp., and the next figure 
showing growth of mixed species of mosses on acidic substratum, where luxuriant growth of Funaria hygrometrica along with Pogonatum, and Polytrichum takes place. These micro communities may change due to overburden of heavily growing tree species like Alnus (Utis) in the said area through progressive change of age of the forest community, at Hill slopes (Photographs taken by Dr. Debabrata Das, on 09.03.2014 in field).
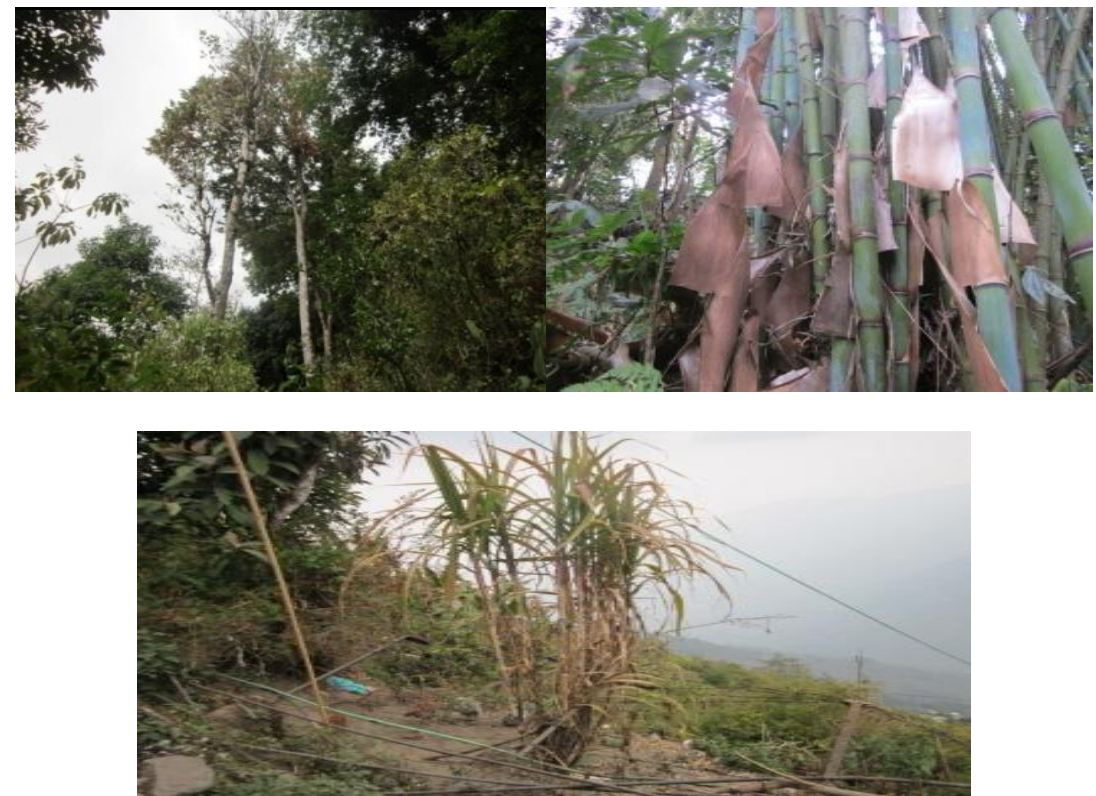

Figure 45-47: Dense Vegetation with Three layered canopy (>70 percent canopy cover) of trees on the ridges of Hills at Mulgaon forest, Bamboo thicket (Parang), Saccharum officinarum L. (Sugarcane locally called Ukhu) in the same village of Darjeeling, West Bengal, India (Photo by Dr. D. Das)

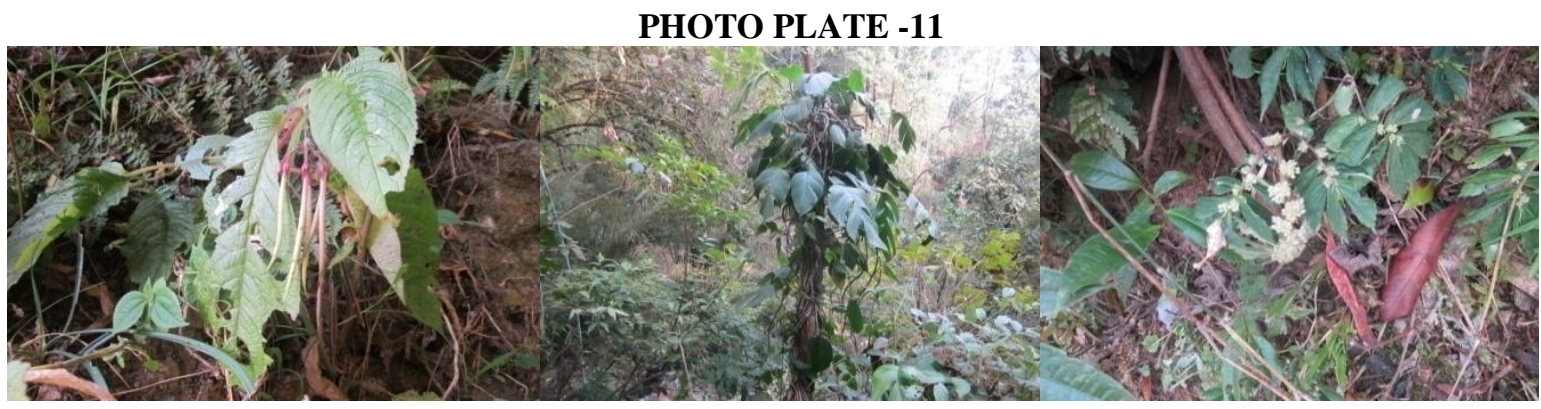

Figures 48-50: Didymocarpus aromaticus Wall. Ex D. Don of Gesneriaceae; Raphidophora decursiva (Roxb.) Schott of Araceae; and Elatostemma sessile Forester \& Forester f. of Urticaceae
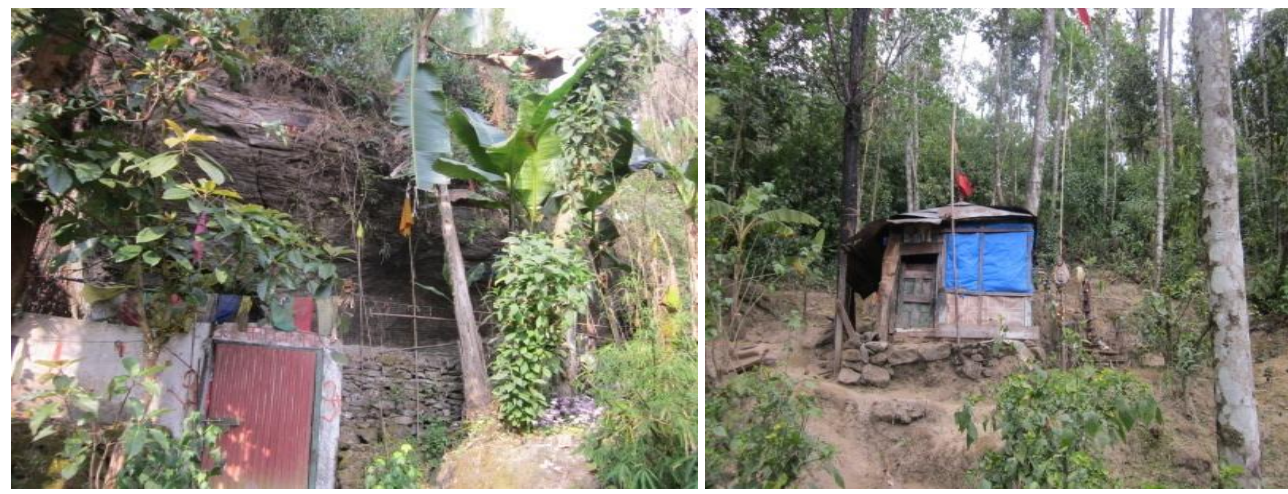


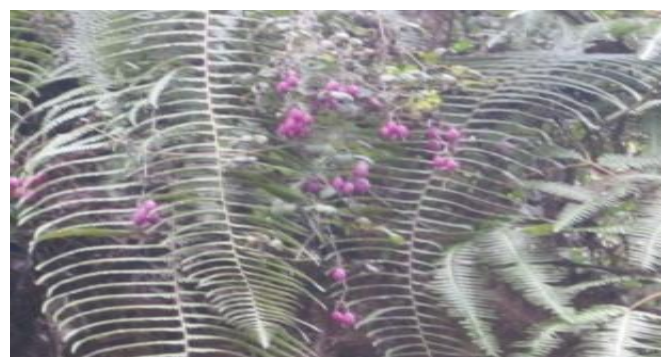

Figures 51-53 : Devimandir (Sacred Grove) at Golaigaon, Mailamama Sacred Grove at Mulgaon, Pink /majenda Fruits are fruits of Dicentra scandens (D. Don.) Walpers hanging over fern leaflets near jhora.(Waste water falls).

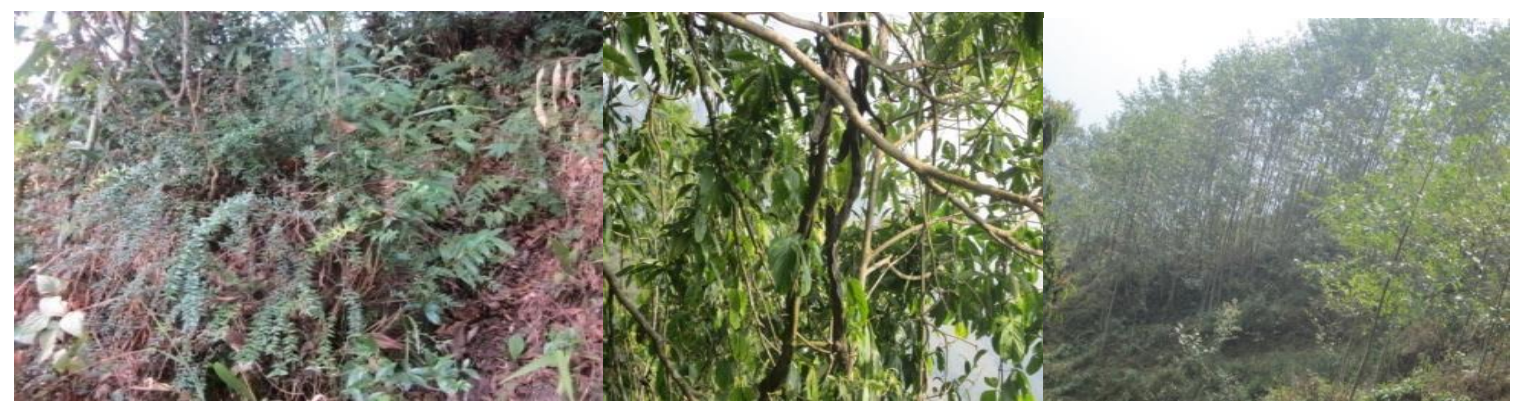

Figures 54-56: Agapetes serpens (Wight) Sleumer on rocky substratum (Bandre) at left, A large climber Mucuna macrocarpa Wall. (Baldhengra) at middle, and Alnus nepalensis D. Don (Utis) at right, Note that, the vegetation of utis at slopes may be $8-10$ years.

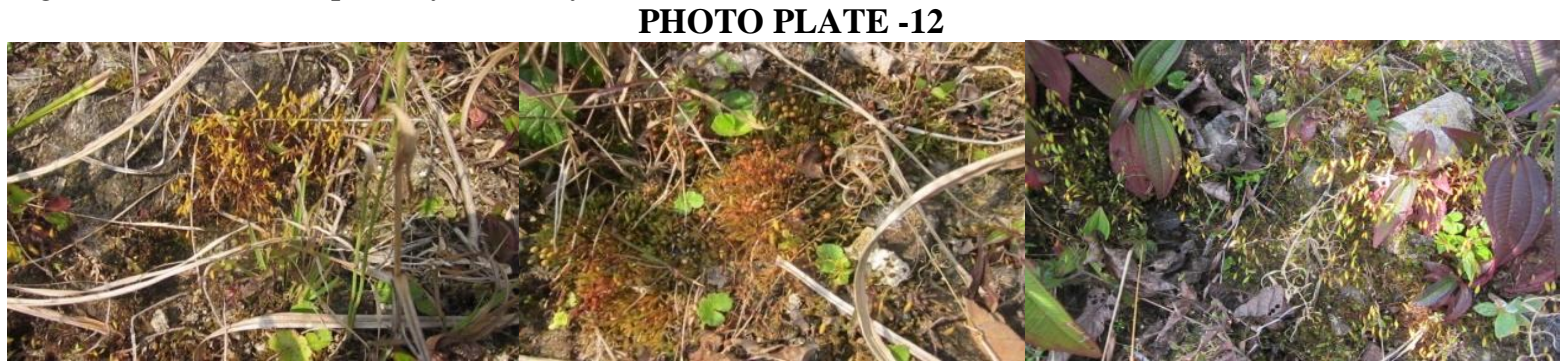

Figures 57-59: Polytrichum commune-community, note that the community having male as well as female plants, male having antheridial clusters and female having sporogonium on rocky substratum, underneath of shrubby vegetation nearby; Polytrichum commune-an endohydric moss community growing underneath tree shade on mildly acidic soil, the hairy cap coming out from capsule so the name hairy cap moss.

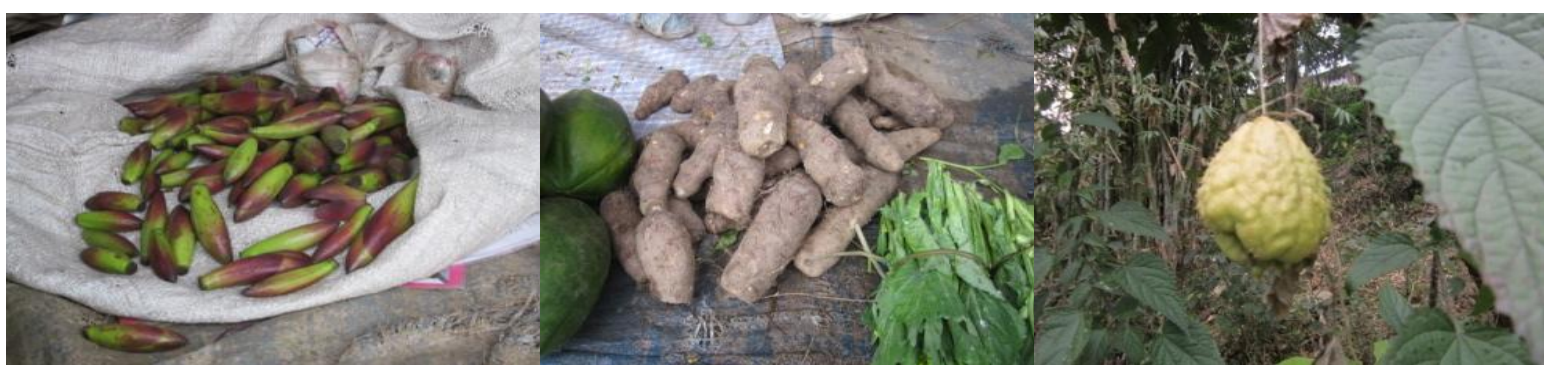

Figures 60-62: Kabra- Ficus benjamina L. var. comosa; , Pindalu-(wild yam i.e. Alocasia sp.) -along with Papaya and Rai-ko-Sag, in a local market, Eskush-Sechium edule (Cucurbitaceae) hanging in a Bamboo thicket during winter near forest. (Note that four varieties of Eskush are available from Kalimpong and Darjeeling areas due to presence of colour and outer spines, one with pale yellow, one with light green, another is dark green, last one is spineless, the light green is very common. This species having light green ecotypes are cultivated throughout the area).

PHOTO PLATE -13 

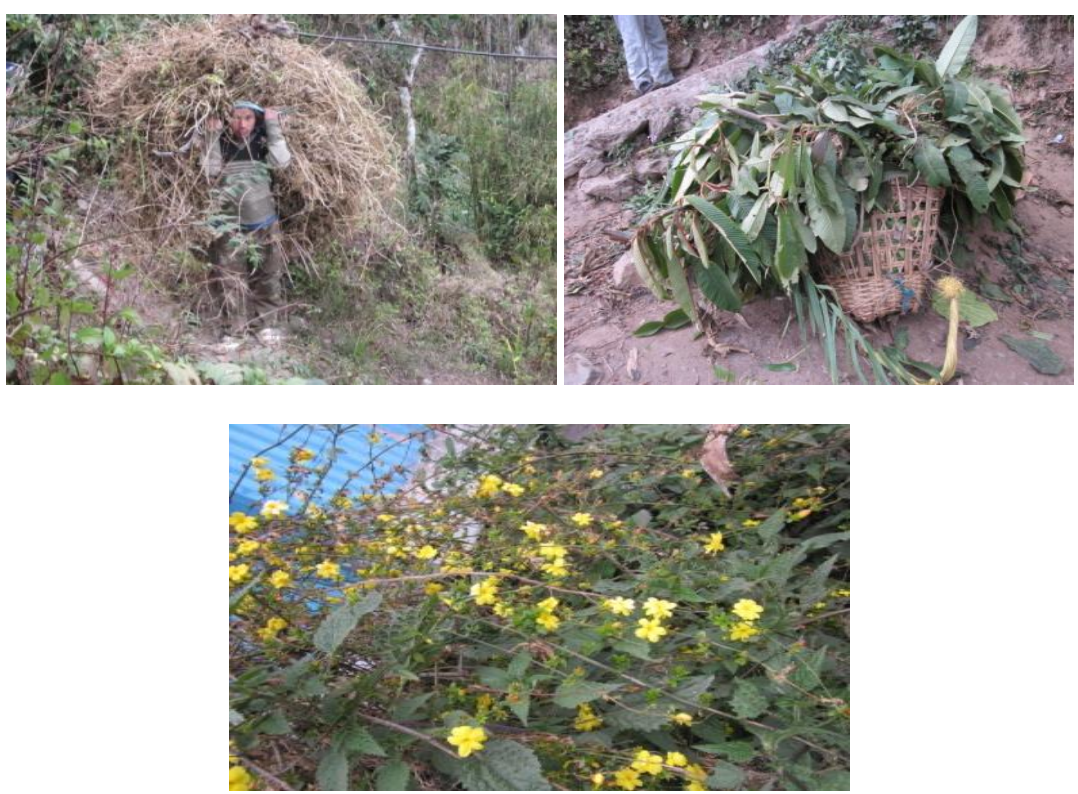

Figures 63-65: People carrying dry litter for fuel purpose; Doka used to carry Fodder plants; Yellow Jasmine: Jasminum humile L. (East Italian Yellow Jasmine) planted for ornamental purpose.
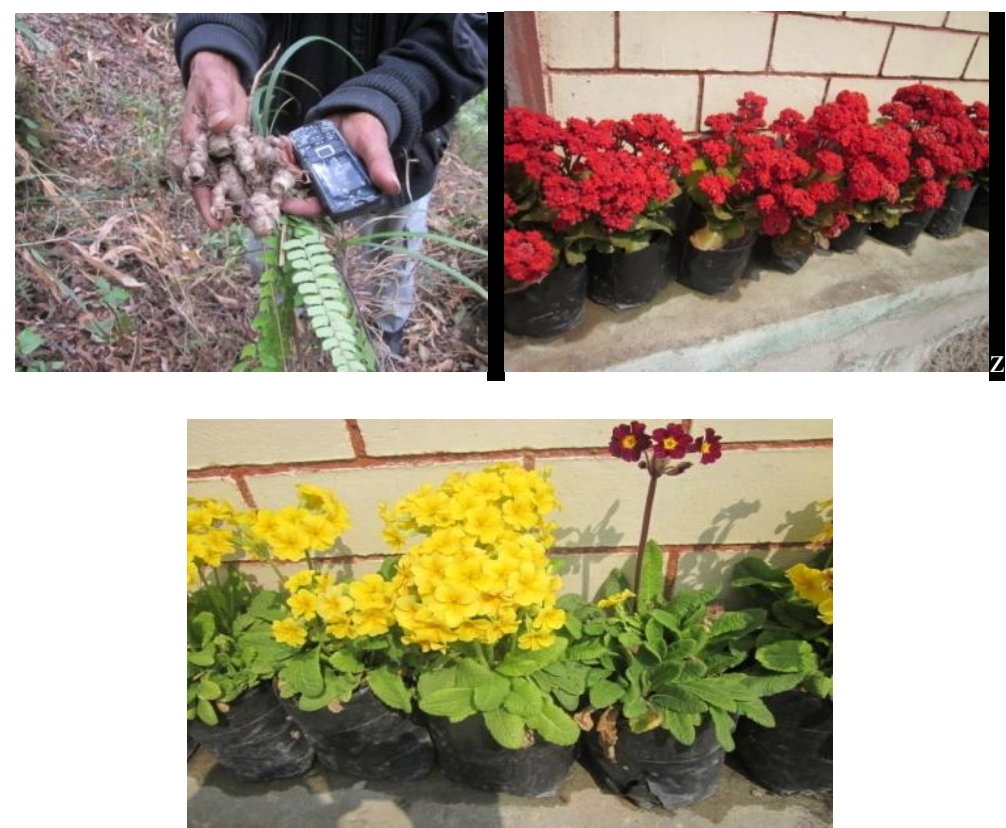

Figures 66-68: Wild Ginger (Zingiber sp.) and fronds of fern ( Nephrolepis sp. -The bulb of underground one called Pani Amla used in Urinary troubles in Men/women ; Kalanchoe garden variety, Colorful Primula (Garden variety) planted in front of the small village house for the medicinal and aesthetic purpose.

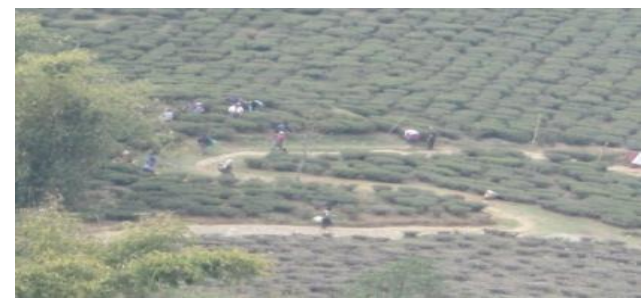

Figure 69: A Landscape diversity of Tea Garden in Eastern Himalaya, Darjeeling where people using Doko for plucking tea leaves, note that this picture is not a picture of Pandam Tea Esatate, it is a Tea garden near Happy Valley Tea Estate, Darjeeling, a view from main road, Darjeeling towards Lebong. 

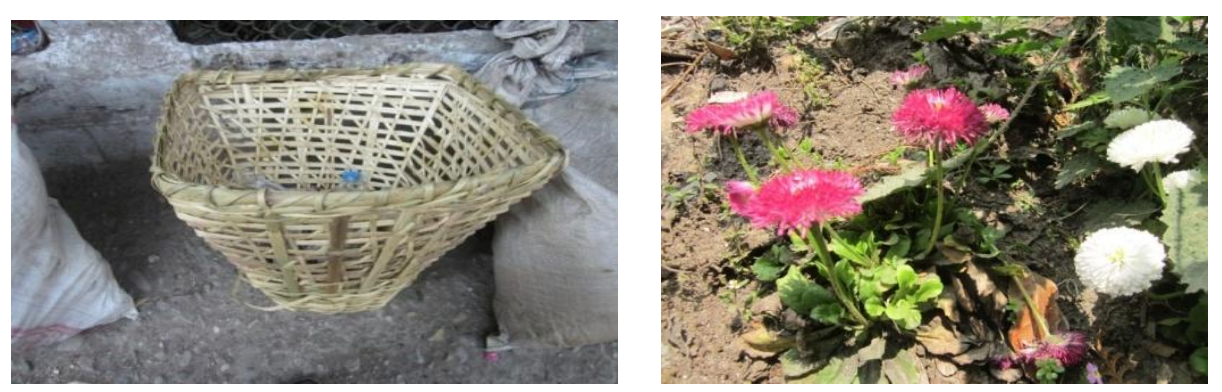

Figures 70-71: Doko of Chaya Bans (Left) and Himalayan Daisy (Pink and White) in village garden used for aesthetic purpose.

\section{Concluding Remarks}

Population of plants, animals and microbes including man has occupied the pace by inter-acting them in each moment and going to re-build their position for temporarily but moderately varied form to adapt them. The concept of landscape ecology has therefore abundant scope for changing human living conditions and shaping ecological character of a region (Dash and Dash, 2010). The Scope of ecology is increasing day by day as it has immense practical values on society. Therefore, demand of this science has expanded considerably as man has become increasingly aware of the serious problems of the environment, and has become so vast that it is now an interdisciplinary science broadcasts activities too a little bit narrow. It is a science which linking biology in one hand and the physical and social sciences in the other hand. Therefore, it includes mode and variations of alternative the pattern, geo-biochemical cycles, energy flow, energy budget, forestry, agriculture and horticulture, Osteo-culture, Dairy, Gotary, Poultry, Duckery, Apiculture, Pisciculture, Pomology and so on. So, this varied science is an interdisciplinary discipline and being amalgamated with technology that dealt with at different levels, namely-(1) the theoretical, perfecting the knowledge of fundamental laws of nature and the functions of biosphere as a whole to cope a little diffraction in environment, (2) the practical, which helps to study the theoretical and provide insights into the understanding of logical problems -besides, these are historical processes of man's transformation of nature and natural processes, (3) the socio-cultural, as ecological processes in recent times have involved the participation of people and changing global scenario which is demandable (e.g. Chipko movement in Uttar Pradesh now Uttarakhand, Silent Valley movement in Kerala, Gandhamadan movement in Odissa (Orissa), and (4) Economical, which means to earn money using different tools and techniques to restore local ecosystem with the help of restoration ecology. In the first two levels scientists play a key role to mitigate the problems, whereas in case of the last two, the people of common type particularly villagers or people of the community, Government, NGOs, trying to mitigate the big problems that predominate in the ecosystem. Therefore, this study is a study of different levels in both villages and in urban areas of Darjeeling Himalaya, as primary type to monitor ecological problems and prospects through vegetation monitoring in the said area. This reflects further scope of research and extension activities either required or not in future do develop society better. Not only that type, has it also broadcast taxonomy, ecology and agriculture of the area which would be helpful for needful eco-restoration in future. It covers structure and functions of tree species for phyto-community study so, after that lower group as well as herb and shrubs composition study is required to know the actual carrying capacity of the ecosystem, for better monitoring of the site. Hope that, researchers will come soon and start the need based work in near future to fulfill the eco-monitoring of the said vegetation as a whole.

\section{ACKNOWLEDGEMENTS}

I express my gratitude to Dr. Kishore Kumar Thapa, Asst. Professor of Botany, Dinhata College, Cooch Behar and a resident of Kalimpong, Darjeeling for proving information to identify the Oranges and some grasses. Thanks provided to Sri. Debasish Aich, Asst. Professor of Physics, Kharagpur College, Paschim Medinipur and a resident of Midnapore town, for great help to identify the orchids of the said area. Professor Aich is an expart of Orchids, who has an own Orchidarium in his house at Midnapore Town. Dr. Projjwal Lama, Dr. Binode Ch. Sharma, Asst. Professors, PG Dept. of Botany, Darjeeling Govt. College are well acknowledged for their valuable suggestions and help as and when required. Librarians, CNH, BSI, Lloyd Botanic Garden Library, Darjeeling Govt. College, and Jhargram Raj College are well acknowledged. Forest officials and Principals of Kurseong College, Darjeeling Govt. College are highly acknowledged. Last But not least thanks are due to forest fringe people of the Darjeeling Himalaya, West Bengal, India for their endless help during field visit. Some of my Nepali PG students are well acknowledged for their cordial help. For financial assistance, Higher education department is well acknowledged. Last but not least thanks are due to Atmaja Avirupa Das, my daughter, who helped me more during compose and typing at Midnapore to prepare the final matter during holidays in April, 2014. For calculation of data, my wife, Pampi Ghosh, Asst. Prof. of Botany, Seva Bharati Mahavidyalaya , Paschim Medinipur, West Bengal, is well acknowledged.

\section{REFERENCES}

\section{Journal Papers:}

[1] Sharma, B. C. Ethnobotanical Plants used against skin diseases by indigenous population of Darjeeling Himalayas, India, Indian Jour. Of Fundamental and Appl. Life Sc., 3(3), 2013, 299-303.

[2] Saha, J; Sarkar, P K and Chattopadhyay, S. A survey of Ethnobotanical pants of Darjeeling Hills for their Antimicrobial and antioxidant activities, Indian Natural Products and Radiance, 2(4), 2011, 479-492.

[3] Rai, S. K. and Bhujel, R.B. Note on some less known ethnomedicinal plants from the Darjeeling Himalayas, J. Hill Research, 12, 1999, 160-163. 
[4] Rai, S. Improved Management of Ginger Diseases, Project report, Published by S. Rai, Principal Investigator, Uttar Banga Krishi Viswavidhyalaya, Kalimpong, 2001

[5] Rai. A; Rai, S and Yonzone, R. Ethnomedicinal plants used by the people of Darjeeling Hills in the Eastern Himalaya of India, Universal Journal of Pharmacy, 2(1), 2013, 122-134.

[6] Saha, S K; Bag, T ; De, A K ; Basak, S; Biswas, S C and Ghosh Roy, S C. Adolescent girls' health profile in sub-Himalayan region of west Bengal, J Obstecol India , 56(4), 2006, 329-332.

[7] Rao, D; Murty, P P and Venkaish, M. Phytosociological observation on the tree species diversity of Tropical forests of Srikakulam District, Andhra Pradesh, India, Indian Jour. Of Plant Sciences (Online), 2(4), 2013, 89-108.

[8 ] Tamang, D. K; Gurung, S; Sharma, N. P. and Shrestha, D. G. Bamboo diversity, distribution pattern and its Uses in Sikkim (India) Himalaya, International Journal of Scientific and Research Publications, 3(2)2013, 1-6

[9] Roy, S. B. Bilateral Matching Institutions: An Illustration in Forest Conservation, The Journal of Indian Anthropological Society of India, 27, 1992, 253-262.

[10] Rohin, D'souza. Rural Development through rural tourism Thinking away from mass tourism, Salesian Journal, Salesian College, Sonada, 2009, pp.-1-6.

[11] Singh, K.K., Kumar, S; Rai, L K and Krishna, A P. Rhododendron Conservation in the Sikkim Himalaya, Current Science, $85(5), 2003,602-606$.

[12] Tiwari, O.N. and Chauhan, U.K. Rhododendron conservation in Sikkim Himalaya, Current Science, 90(4), 2006, 532-541.

[13] Singh, K. K.Notes on the Sikkim Himalayan rhododendrons: a taxon of great conservation Importance, Turkish Jour. Of Botany, 33(4), 2009, 305-310.

[14] Menon, S; Khan, M L ; Paul, A; Peterson, A T. Rhododendron species in the Indian Eastern Himalaya: New approach to understanding Rare Pant species distribution, Journal of American Rhododendron Society, Spring, 2012, 78-84.

Books:

[15 ] Bhujel, R. B. Studies on the Dicotyledonous Flora of Darjeeling District, Ph. D. Thesis,1996, North Bengal University, Siliguri, Darjeeling.

[16] Greipsson, S. Restoration Ecology, Jones \& Bartlett Learning, USA, 2011, pp-387.

[17] Roy, S.B; Mukhopadhyaya, D and Das, S. Strengthening Institutions in Joint Forest Management Systemic approach to Forest Conservation, Social Science, New Delhi, 2001.

[18] Groom, M. J; Meffe, G K ; Carroll, C. R. and Contributors. Principles of Conservation Biology, Third Edition, Sinauer Associates, Inc. Publishers, USA.,2006, pp.-793.

[19] Anonymous. Handbook of Ecological Indicators for Assessment of Ecosystem Healthy, Second Edition, edited by Sven E. Jorgensen, Fu-Liu Xu and Robert Costana, CRC Press, Taylor and Francis Group,2010, pp. 484.

[20] Tamang, K. K. and Yonzone, G. S. Dictionary of Flowering Plants of Darjeeling-Sikkim Himalaya (along with their corresponding Nepali and English names), Mani Printing House, Darjeeling, West Bengal, India.2004, pp:1 -70.

[21] Stainton, A. Flowers of the Himalaya, A Supplement, Oxford University Press, Eighth Impression, New Delhi, 2011, India.

[22] Polunin, O and Stainton, A. Flowers of the Himalaya. Oxford University Press, Twelfth Impression, New Delhi, 2012, India.

[23] Hooker, J.D. Flora of British India, Vol.-1-7, 1892-1897, BSI, Kolkata.

[24] Prain, D. Bengal Plants (Vol.-I/II), Bishen Singh and Mahendra Pal Singh, 1963 (Revised), Dehradun, India.

[25] Anonymous. Flora of West Bengal, Vol.-I, 1997, Flora of India, Series-2, BSI, Kolkata.

[26] O’Malley, L.S.S. Darjeeling: Bengal District Gazetters, New Delhi, 1907, Logos Press.

[27] Bennet, S.S.R. Name Changes in Flowering Plants of India and adjoining Regions, Triseas Publishers, 1987, Dehra Dun.

[28] Jain, S. K. and Rao, R. R. A Hand Book of Field Herbarium Methods, Oxford IBH Publishing Company, 1997, New Delhi.

[29] Kirtikar, K.R. and Basu, B.D. Indian Medicinal Plants, I-IV, International Book Distributors, 1918, Dehra Dun.

[30] Malhotra, K.C; Deb, D; Dutta, N; Vasulu, T.S; Yadav, G and Adhikari, M. Role of Non-Timber Forest Produce in Village Economy: A Household survey in Jamboni Range, Midnapore District, West Bengal, IBRAD, 1991, Calcutta.

[31] Roy, S.B; Mahapatra, T and Yadav, G. Forest Protection and management by communities in Midnapore District, West Bengal, published in the book,"Joint Forest Management and Community Forestry in India-An Ecological and Institutional Assessment" Edited by N H Ravindranath; K S Murali and K.C Malhotra, Oxford IBH Pub. Co. Pvt. Ltd., 2000.

[32] Kurane, A. Ethnic Identity and Social Mobility, Rawat Publications, Jaipur, 1999, pp.-32-37.

[33] Bhui, Ujjwal. Gorkhaland Movement and ethnic conflicts in Dooars: Some Observations and Opinions, The Himalayan Miscellany, Vol-19 \& 20, 2008-09, Centre for the Himalayan Studies, North Bengal University, Raja Rammohunpur, Siliguri, Darjeeling, pp.-19-30.

[34] Anonymous, Effectivenes Monitoring guidelines for Ecosystem Restoration, Final Report, submitted to-Habitat Branch, Ministry of Water, Land and Air Protection, Stn. Prov. Govt., Jutland Road, Victoria, prepared by-Marine Machmer and Christoph Steager, Pandian Ecological Research Ltd., 705-Stanley, 2002, Nelson.

[35] Dash, M C and Dash, S P. Fundamentals of Ecology, Third Edition, The McGraw-Hill Companies, 7 West Patel Nagar, New Delhi, Chapter-5, 2010, pp-222.

Thesis:

[36] Das, D. Vegetation Ecology of Forests of South West Bengal with special reference to Non-Timber Forest Produce (NTFPs) Productivity, Ph. D Thesis awarded from Vidyasagar University, 2007, West Bengal (Work From CNH, Botanical Survey of India, Shibpore, Howrah, West Bengal).

\section{Other articles:}

[37] Anonymous. Information Booklet, GTA Election 2012, pp. 103

[38] Dey, N. Ecological study of some herbaceous medicinal Plants of Darjeeling Himalaya with special reference to Vasicular Mycorrhizal infection, Dissertation Work for M.Sc. Degree in Botany, from Darjeeling Govt. College, under North Bengal University, West Bengal (Supervisor, Dr. Debabrata Das, Asst. Prof. of Botany, Angiospermic Taxonmy and Ecology Laboratory, Darjeeling Govt. College, Darjeeling), 2013, pp-1-40. (Unpublished, un-uploaded).

[39] Web article: Michelia cathcartii Hook.f. T. NYPL DIGITAL COLLECTIONS, Beta ;Still image, RLIN/OCLL: 11864249, NYPL Catalog ID (B. Number):b14444153 (Illustrations of Himalayan Plants: Chiefly selected from drawings made for the late J.F.Cathcart, Esq.re of the Bengal Civil Service, website: http:/digital collections.nypl.org/items/510dc47dc-5090-a3dge040a18064a99

[40] Anonymous. Environmental Science: In Context, Vol.-I (Acid Rain to Logging), Brenda Wilmoth Lerner \& K. Lee Lerner, Editirs, GALE CENGAGE Learning, 2008.,pp-537.pp.244. 